\title{
Recent Advances in Plasmonic Sensor-Based Fiber Optic Probes for Biological Applications
}

\author{
M. S. Aruna Gandhi ${ }^{1}$ (D), Suoda Chu ${ }^{2}$, K. Senthilnathan ${ }^{3}$, P. Ramesh Babu ${ }^{3}$, K. Nakkeeran ${ }^{2}$ and \\ Qian Li ${ }^{1, *}$ \\ 1 School of Electronic and Computer Engineering, Peking University, Shenzhen 518005, China; \\ aruna@pkusz.edu.cn \\ 2 School of Engineering, University of Aberdeen, Aberdeen AB24 3UE, UK; r05sc15@abdn.ac.uk (S.C.); \\ k.nakkeeran@abdn.ac.uk (K.N.) \\ 3 School of Advanced Sciences, Vellore Institute of Technology, Vellore 632014, India; \\ senthee@gmail.com (K.S.); prameshbabu@vit.ac.in (P.R.B.) \\ * Correspondence: liqian@ece.pku.edu.cn; Tel.: +86-755-2603-2320
}

Received: 30 December 2018; Accepted: 1 March 2019; Published: 6 March 2019

\begin{abstract}
The survey focuses on the most significant contributions in the field of fiber optic plasmonic sensors (FOPS) in recent years. FOPSs are plasmonic sensor-based fiber optic probes that use an optical field to measure the biological agents. Owing to their high sensitivity, high resolution, and low cost, FOPS turn out to be potential alternatives to conventional biological fiber optic sensors. FOPS use optical transduction mechanisms to enhance sensitivity and resolution. The optical transduction mechanisms of FOPS with different geometrical structures and the photonic properties of the geometries are discussed in detail. The studies of optical properties with a combination of suitable materials for testing the biosamples allow for diagnosing diseases in the medical field.
\end{abstract}

Keywords: plasmonics; photonics; fiber optic probes; surface plasmon resonance; metal; dielectric; refractive index; analyte; biosamples

\section{Introduction}

In recent years, the surface plasmon resonance (SPR)-based optical sensing of several quantities such as chemicals [1,2], temperature [3], pressure [4], force [5], environmental monitoring [6], optofluidic detection [7], food safety [8], and biological species [9,10], as illustrated in Figure 1 [11-14], has been proven to be advantageous. The optical fiber deployed in such sensors has replaced the traditional substrates for SPR sensors such as prisms, electrodes, etc. [15]. Today, SPR-based optical sensors are employed for different applications in life sciences, electrochemistry, environmental safety, and biomedical diagnostics, as illustrated in Figure $1[16,17]$. SPR is a promising and powerful optical detection technique for studying label-free biomolecular interactions in real time within a variety of diverse biomedical applications due to the label-free sensing, fast response, and high sensitivity [18-20]. Several SPR-based optical fiber sensing configurations are widely proposed, and fiber optic sensing configuration allows for simplified designs [21,22]. Recently, researchers have found that these SPR-based FOPSs are applied in remote sensing over the prism-based SPR sensing devices [1]. The most beneficial aspect of FOPSs is their ability to analyze minute quantities of biological samples [23]. Thus, SPR-based FOPSs have received a lot of attention in the recent past [24]. 


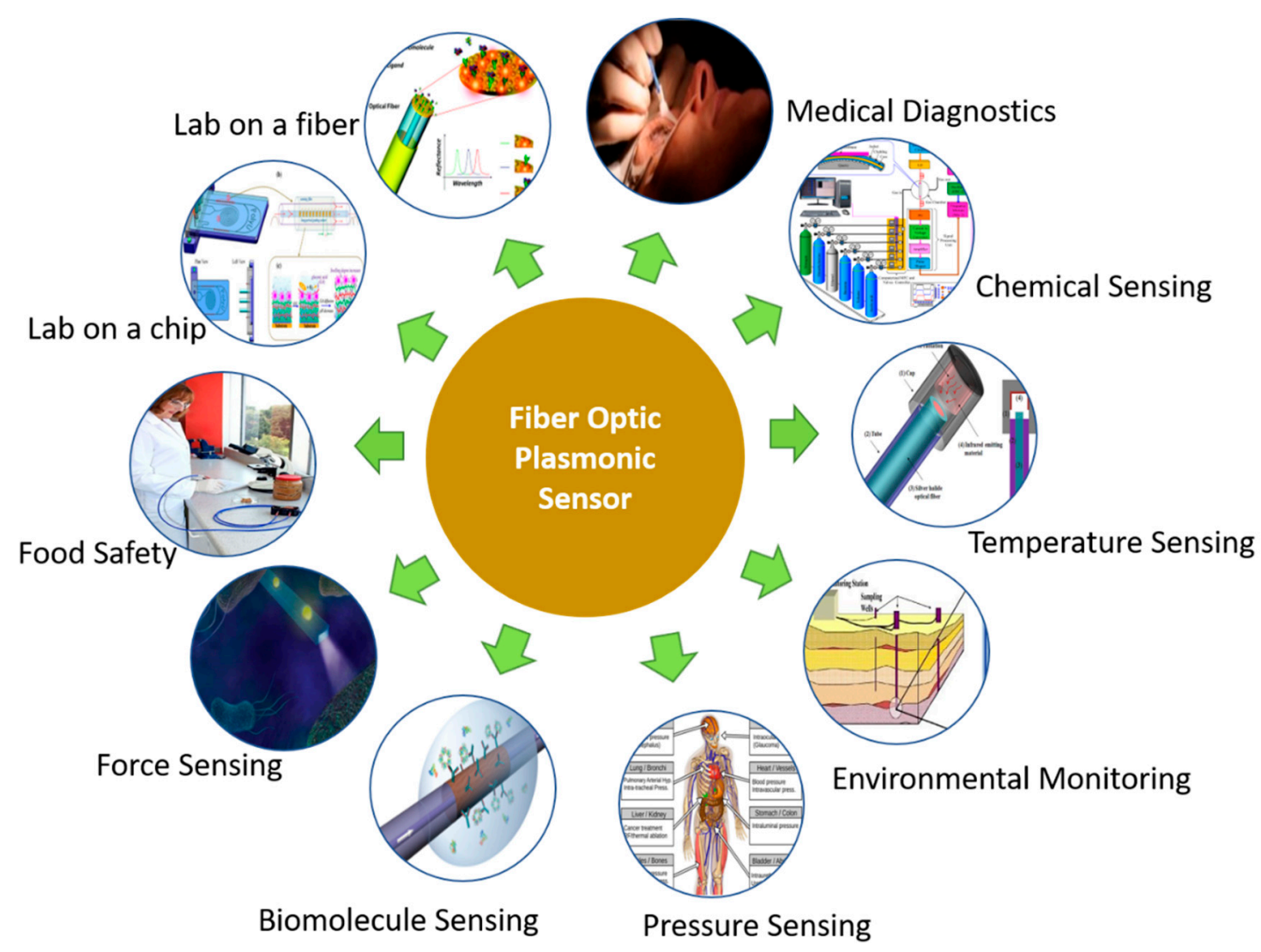

Figure 1. Biological applications of fiber optic plasmonic sensor [11-14,16,17].

We start this review with a brief discussion of some SPR-based FOPSs that find wide application because of their simple structure, compactness, high resolution, and sensitivity. The geometrical configurations of different FOPSs with single mode and multimode fibers for sensing applications are discussed $[25,26]$. As the propagation modes in multi-mode fibers are nearly random, the mode distribution at different incident angles is unstable [27]. As only part of the light beams undergoes resonance, it directly influences the sensing performance, reliability, and repeatability. Hence, for multimode optical fiber plasmonic sensors, the signal-to-noise ratio limits the measurable range of the sensitivity and resolution. Although there is some related work already reported for constant-angle SPR sensor design [28-30], a number of unexpected incident angles were still involved in their designs. In addition, multimode optical fibers are sensitive to mechanical disturbance and hence the quality of the output signal is lowered as well [31]. In contrast, a single-mode fiber exhibits a narrow resonance dip in the transmission spectrum, which results in an improved detection limit. Thus, to enhance the resolution, the single-mode optical fiber plasmonic sensor has been established [32]. Generally, the geometric structure of the FOPSs consists of two media, namely, dielectric and metal. The sensing mechanism between the dielectric silica cladding with various metal-coated surfaces is attributed to the surface plasmon resonance.

Nowadays, in order to enhance the sensitivity and resolution of SPR-based FOPS, a thin layer of graphene and molybdenum disulfide is added to the metal layer [33-35]. Furthermore, other combinations, namely, molybdenum disulfide, molybdenum diselenide, tungsten disulphide, and tungsten diselenide layers (transition metal dichalcogenides), have also been developed [21,36]. In this review, we briefly discuss the different geometrical configurations of the SPR-based FOPS with various combinations of transition metal dichalcogenides for biomedical applications. 


\section{Physics of Surface Plasmons}

A quantum of a collective oscillation of free electrons that are confined evanescently on the surface of a metal surface induced by an electromagnetic field is known as surface plasmons (SPs), a term that was introduced by Ritchie in 1957 [37]. SPs that propagate in the transverse magnetic (TM) direction (p-polarized) are known as surface plasmon waves (SPWs). In what follows, we discuss surface plasmon polaritons (SPPs) and localized surface plasmon polaritons (LSPPs) in detail.

\subsection{Surface Plasmon Polaritons}

The interaction between the photon and the polar excitation of electric dipoles in a semiconductor or at the surface of a metal is known as a polariton. The strong coupling of the surface plasmons with the polaritons is called SPPs, shown in Figure 2. The propagation of SPPs takes place when the electromagnetic field strikes the free electrons in the interface of two media having negative and positive real parts of permittivity (a metal and a dielectric medium). The plasma oscillation is optically excited at the interface, which consists of positively charged ions on the planar metal layer surface. Therefore, the density of the electromagnetic field at the metal surface will not be the same. The positively charged ion background will attract the negatively charged free electrons. Hence, the movement of electrons takes place when the density of free electrons is lower than the average density in the given volume. The attracted electrons gain additional momentum and gradually grow in density. Therefore, a large number of negative electrical charges are formed. The coulombic repulsive force among the free electrons induces them to separate and the collective electron density oscillation is established. Therefore, an electromagnetic surface wave is generated due to the plasma oscillation. The quantum of plasma oscillation is referred to as SPP and is illustrated in Figure 2.

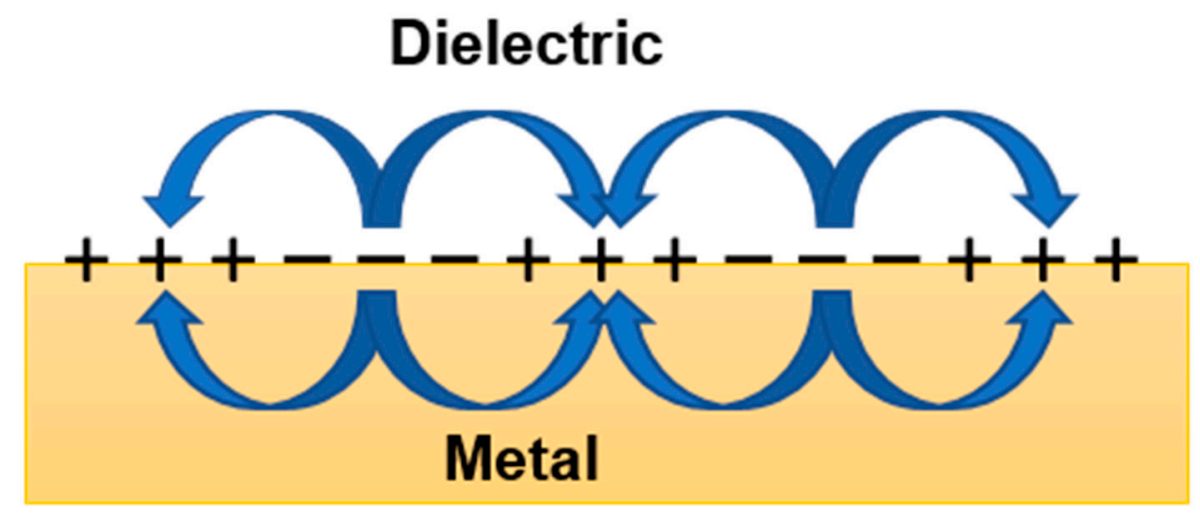

Figure 2. Schematic illustration of surface plasmons propagating at the interface between metal and dielectric [38].

\subsection{Localized Surface Plasmon Polaritons}

The interaction between the surface of the metal nanoparticle and the electromagnetic field that results in strong oscillations/damping is known as LSPPs. The propagation of SPs in the LSPPs is similar to the SPPs. In LSPPs, the collective oscillations of the free electron cloud are shown in Figure 3. The light scatters from a topological defect on the surface of the metallic particles or nanostructures [38,39]. In contrast with the SPPs, in which the coupling occurs at the surface of the metal layer, the collective oscillations of the free electron cloud in LSPPs are confined in metal nanoparticles or nanostructures [40]. 


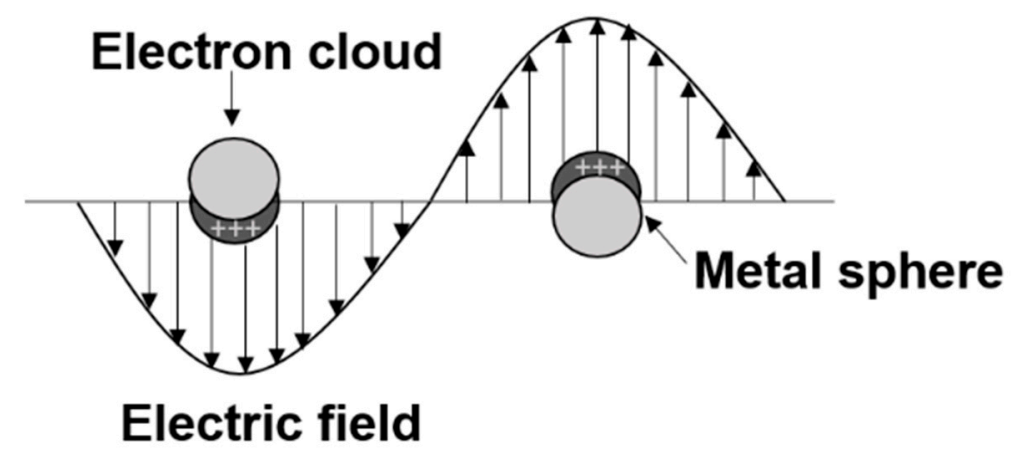

Figure 3. Schematic illustration of surface plasmons propagating at the interface between metal nanoparticle and dielectric materials [40].

\section{Resonance Conditions}

As the SPP and LSPP have different coupling mechanisms, the resonance condition for two different polaritons also needs to be explained in terms of the surface plasmon resonance and localized surface plasmon resonance.

\subsection{Surface Plasmon Resonance}

The resonant oscillation of the conduction electrons at the interface between the dielectric and metal stimulated by an electromagnetic wave is known as SPR, an underlying principle widely used in sensing applications nowadays. SPR can be excited by the photons or electrons [38]. It is known that SPs are excited by the evanescent waves under the resonance condition. When the propagation constant of an incident light is equal to that of the collective oscillation of surface electrons in the metal, their momenta can be matched, and hence resonance occurs. Thus, SPR is highly sensitive to variations in the refractive index (RI).

\subsection{Localized Surface Plasmon Resonance}

LSPR is an optical phenomenon that arises when the incident light wave is trapped within conductive nanoparticles with dimensions smaller than that of the wavelength of the light [41]. While SPs propagate along the continuous metal surfaces, LSPs are localized around the surface of the nanoparticles. Under the resonance condition, metal nanoparticles will present a strong absorption band of light that will enhance their damping amplitude [42]. Recently, the particle-optical wave excitation, which occurs in the visible wavelength region for noble metal nanoparticles with dimensions smaller than the wavelength of incident light, is reported [43].

\section{Theoretical Framework}

Generally, SPs are excited by the photons in SPR-based optical sensors. SPs are optically excited when the wave vector of the electromagnetic wave matches that of SPs, which is known as the phase-matching condition or resonance condition. Next, we discuss the different excitation methods of SPs with the prism, grating, and waveguide.

\subsection{SPR in Prism Configuration}

The Kretschmann configuration [44] is commonly used in most SPR applications nowadays, as shown in Figure 4a, and was developed and improved from the Otto configuration [12] shown in Figure $4 \mathrm{~b}$. In the Otto configuration, an air gap layer (dielectric constant, $\varepsilon_{s}$ ) lies between the prism (dielectric constant, $\varepsilon_{p}$ ) and the metal layer (dielectric constant, $\varepsilon_{m}$ ). The evanescent wave at the prism-air interface can excite the SPs at the air-metal interface. Total internal reflection takes place inside the prism when the electromagnetic field propagates from the prism (high refractive index, $n_{1}$ ) to the air gap layer (low refractive index, $n_{2}$ ). 


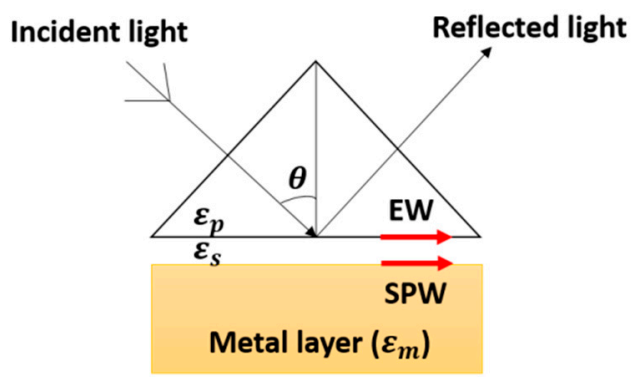

(a)

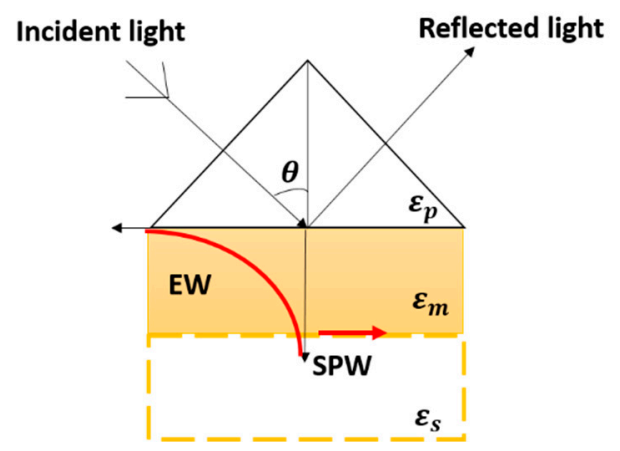

(b)

Figure 4. (a) Otto configuration and (b) Kretschmann configuration for the excitation of surface plasmon at the metal-dielectric interface [23].

The incident angle, $\theta_{a}$, should be greater than the critical angle, $\theta_{c}$, in order for the total internal reflection to take place. Nevertheless, some part of the electromagnetic field is propagated at the prism-air interface as an evanescent wave. However, as it decays over a distance of the interface of the entail air gap, the SPR efficiency is reduced.

Hence, in the Kretschmann configuration, the prism was coated by the metal directly without an air gap and the other side of the metal layer was designed for placing a dielectric sample. In order to enhance and maintain the propagation of this evanescent wave, a gold or silver film with a suitable thickness is placed between the two media and dielectric sample (air). The most used metal is either gold or silver, which can provide a real but negative dielectric constant, whereas for the dielectric sample (air) it is positive.

The wave vector for the evanescent wave, $k_{e w}$, is given as

$$
k_{e w}=\frac{2 \pi}{\lambda} n_{1} \sin (\theta),
$$

where $\lambda$ is the incident wavelength, $n_{1}$ is the higher refractive index of the prism, and $\theta$ is the incident angle.

The wave vector of the SPs is explained with the dielectric constant of the metal (refractive index, $n_{g}$ ) and dielectric sample (refractive index, $n_{2}$ ) and is given as

$$
k_{S P}=\frac{2 \pi}{\lambda} \sqrt{\frac{n_{2}^{2} n_{m}^{2}}{n_{2}^{2}+n_{m}^{2}}} .
$$

In Equation (2), $n^{2}=\varepsilon$. Here, $\varepsilon$ is the dielectric constant and $n$ is the refractive index. When the propagation constant of the evanescent wave is equal to that of SPs $\left(k_{e w}=k_{S P}\right)$, SPR can be achieved by the transfer of light wave energy into the SPs. The evanescent wave in the metal film is expressed as

$$
k_{S P R}=\frac{1}{n_{1} \sin \theta} \sqrt{\frac{n_{2}^{2} n_{m}^{2}}{n_{2}^{2}+n_{m}^{2}}},
$$

where $\theta$ is the resonance angle.

\subsection{SPR in Grating Configuration}

The in-plane wave vector of the incident electromagnetic field on the metal-dielectric interface is increased to match the associated surface plasmons by a diffraction grating, $G$ as shown in Figure 5 . The x-component of wave vector of the incident light, $k_{x}$, is increased by $G$ through the order of the diffraction order, $m=+1$ to match that of the surface plasmons [45]. 


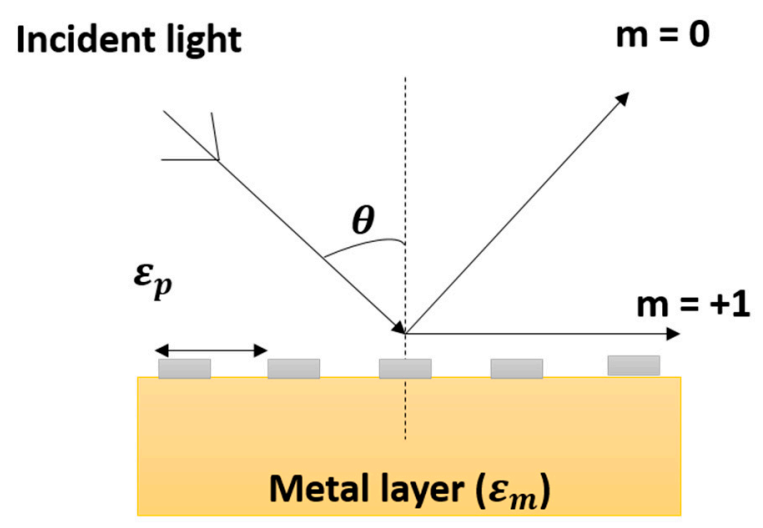

Figure 5. Excitation of surface plasmons by the diffraction grating method [45].

The propagation constant of the electromagnetic field on the surface of the grating is given as

$$
k_{S P R}=k_{x}+m G \quad k_{S P R}=\frac{2 \pi}{\lambda} n_{1} \sin (\theta)+m \frac{2 \pi}{\Lambda},
$$

where $k_{S P R}$ is the propagation constant of the diffracted light of the grating, $k_{x}$ is the propagation constant of the electromagnetic field, $m$ is the diffraction order $(m=0, \pm 1, \pm 2, \pm 3, \ldots), G$ is the wave number of the grating, $\Lambda$ is the grating period, and $n_{1}$ is the refractive index of medium 1 .

\subsection{SPR in Waveguide Configuration}

In waveguide configuration, the electromagnetic field propagates through the guided modes in the metal-dielectric region and its evanescent wave can penetrate the thin metal film, as shown in Figure 6.

Guided wave in
Guided wave out

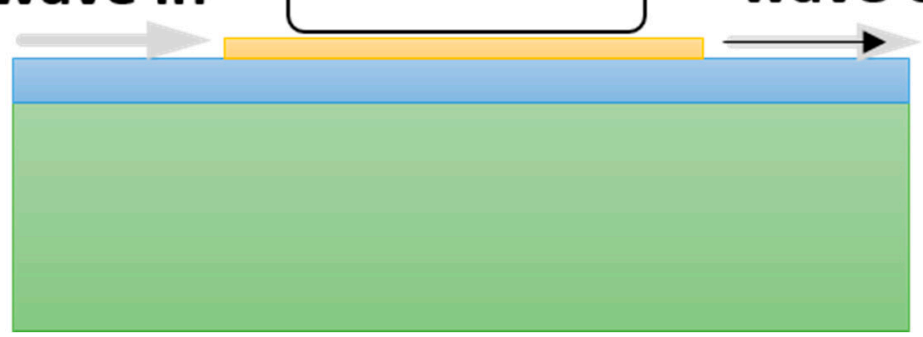

Figure 6. Excitation of the surface plasmons by waveguide coupling. Green layer indicates substrate, blue indicates waveguide, yellow indicates metal film, and black rectangle on the top indicates the dielectric [46].

The resonance is achieved when the wavelength-dependent propagation constant of the guided mode matches that of the surface plasmon mode at the interface of the metal-dielectric region [46]. Therefore, the transmitted spectrum can be observed for the sensing analysis.

\section{FOPS Performance Evaluation}

The dependence of the SPW on the changes of analyte RI is the underlying principle used in FOPS detection [47]. There are three main critical parameters for evaluating FOPS performance. 


\subsection{Sensitivity}

The sensing sensitivity of FOPS can be determined by the degree of discrimination of resonance wavelength shift or intensity change caused by the variation of RI of the analyte, namely wavelength interrogation and amplitude interrogation. The sensitivity of wavelength interrogation can be expressed as $\mathrm{S}_{\lambda}(n m / R I U)=\Delta \lambda_{\text {peak }} / \Delta n_{a}$. Here, $\Delta n_{a}$ is the analyte RI variation for an RI-based FOPS system (this can also be defined in terms of other variables, for example, variation in temperature for the detection of temperature sensor or variation in liquid concentration as a chemical sensor) and $\Delta \lambda_{\text {peak }}$ is the resonance wavelength peak shift [48]. In comparison to wavelength interrogation, amplitude interrogation has the advantages of simple technical requirements and low cost. It can be defined as $S_{A}(\lambda)\left(R I U^{-1}\right)=-\left(\partial a\left(\lambda, n_{a}\right) / \partial n_{a}\right) / a\left(\lambda, n_{a}\right)$, where $a\left(\lambda, n_{a}\right)$ is the lost energy of the core mode for a particular wavelength [49]. However, this method suffers from the disadvantages of low sensing capability and a small operational range.

\subsection{Linearity}

Linearity presents the ratio between the transducing parameter and measurand, which can reflect the sensing stability of the entire system during the detection. A high linearity response of regression line indicates a good sensor [50]. For an RI-based FOSP system, the linearity can be plotted between the loss resonance wavelength and analyte RI.

\subsection{Figure of Merit}

Figure of merit (FOM) is one of the important parameters related to the signal-to-noise ratio (SNR) to evaluate the FOPS sensing performance by introducing the spectral width [51]. It can be given by the equation of FOM $=S / F W H M$, where $S$ is the wavelength interrogation sensitivity and FWHM represents the full width at half-maximum of the spectra [52].

\section{FOPS Geometrical Configuration and Techniques}

Recent FOPS can be categorized based on the geometry of sensor probes and are discussed in what follows. Moreover, some novel SPR sensor techniques developed in the last few years are also discussed.

\subsection{Conventional Optical Fiber Sensors}

Conventional fibers are modified to trap the light inside the core, which is in direct contact with the surrounding medium and hence acts a sensor, as sketched in Figure $7 \mathrm{a}-\mathrm{h}[46,53]$. All or part of the cladding of the fiber is removed by chemical itching or side polishing for the sensing applications. These uncladded or D-shaped optical fiber sensors are established and studied in the operating wavelength range from 500 to $800 \mathrm{~nm}$ [46]. The incident light launched into the fiber core, i.e., fundamental mode, at a certain wavelength can couple with the plasmonic mode. Then, the particular effective refractive index of the analyte is monitored for the characteristics of the transmission light. Nevertheless, achieving the phase matching condition is challenging. The coupling between the effective refractive index of the plasmonic mode and the effective refractive index, $n_{\text {eff }}$, of the core mode takes place at higher frequencies. Tuning the phase-matching condition in the desired wavelength has been achieved with multimode fibers by coupling the effective refractive index of higher-order modes and effective refractive index of the plasmonic mode $[25,54,55]$. The tapered optical fibers, as shown in Figure 7a, are produced by removing the cladding of the fiber [56]. The unclad part is fixed with translational stages at both the ends. The center part of the unclad fiber is heated with burning gas and the fiber is slowly pulled at both ends to reduce the waist diameter of the fiber. A thin metal layer is placed on the tapered region and exposed to the surrounding for sensing [56]. Such unclad/etched/tapered structured sensors have achieved a maximum sensitivity of 20,000 nm/RIU in RI (refractive index)ranging from 1.415 and 1.429 [57]. A RI sensor based on dual-core photonic 
crystal fiber (PCF) has exhibited the highest sensitivity of 22,983 nm/RIU [58]. The so-called N-layered matrix method is also followed for the unclad/etched structure sensor configuration, as elucidated in Figure $7 \mathrm{~b}$ [22]. In the N-layered matrix method, to analyze the reflectance and transmittance properties, the following three methods are surveyed, namely, the field tracing method, the resultant wave method, and the transfer matrix method [59]. The characteristics of better sensitivity with enhanced detection accuracy and figure of merit are endowed by this transfer matrix method $[22,60]$. In recent years, the fabrication techniques provide several geometries for the metal components, as shown in Figure 7c, which are used for tailoring the modal dispersion of the plasmons and to increase their coupling with the fundamental mode [61]. The metallic wires support multiple modes, which are responsible for the increased number of resonant peaks that result in the sensor with different values of refractive index detection range and operating wavelengths [62]. Nanocoated D-shaped optical fibers were constructed for sensing applications with a sensitivity of $1566 \mathrm{~nm} / \mathrm{RIU}$ [63]. A single mode D-shaped fiber is used for sensing the RI monitoring of liquid with linearity up to 0.984 [64]. The multi-D-shaped optical fiber has been established by forming several D-sections in an optical fiber as a highly sensitive RI sensor with the resolution of $1.27 \times 10^{-3}-3.13 \times 10^{-4}$ RIU [65].

\subsection{Grating-Assisted Fiber Sensors}

The gratings are photo-inscribed inside the core region and some part of the light is given in the cladding region. This effect has been used to develop the SPR-based FOPs [41]. In what follows, we discuss various types of grating-assisted fiber sensors such as thinned fiber Bragg gratings (ThFBGs), long-period fiber Bragg gratings (LFBGs), and tilted fiber Bragg gratings (TFBGs). Recently, ThFBGs have been established for RI sensing applications with a resolution of $10^{-5}-10^{-4}$, as shown in Figure 7d [66]. LFBGs have been proposed to achieve SPR of a single cladding mode at the gold-coated tip of a single mode fiber [67], as shown in Figure 7e. Recently, sensors based on TFBGs have exhibited a sensitivity of $500 \mathrm{~nm} / \mathrm{RIU}$ in non-plasmon-assisted refractometry and bulk optic SPR sensors, as shown in Figure 7f [68].

\subsection{Specialty Fibers}

The specialty fiber configurations of this group are non-conventional fibers. In this line, the polarization-maintaining optical fibers support two linearly polarized modes, namely, slow and fast polarizations. When one of the polarized modes is aligned with the metal layer, the other modes tend to exhibit the SPR mode. A polarization mode fiber sensor has been demonstrated with refractive index resolutions better than $4 \times 10^{-6}$ RIU [69]. Over the years, in order to enhance the sensitivity of the fiber sensors, there has been continuous engineering done on the geometry of the fiber. This has led to notable advances in sensor technology.

Recently, microstructured optical fibers (MOFs) have attracted more interest due to their usefulness in design engineering. MOFs are mostly modeled with air holes in the cladding region surrounded with metal over the core region, as shown in Figure 7g,h [70]. The several SPR-based FOPs reported so far have been classified into five categories, namely, nanowire based, micro-fluidic slotted based, internal metal coated, external sensing type, and D-shaped. In the mentioned techniques, the sensitivity has been achieved by coating the metal in the air holes and filling the analyte selectively in the cladding air holes. By engineering the geometric structure of the MOFs with various structural parameters, a maximum sensitivity of $21,700 \mathrm{~nm} / \mathrm{RIU}$ has been achieved [71]. In this line, several different configurations, namely, three-hole, multi-core, grapefruit, and higher-order asymmetric MOFs have been demonstrated [72-79]. 

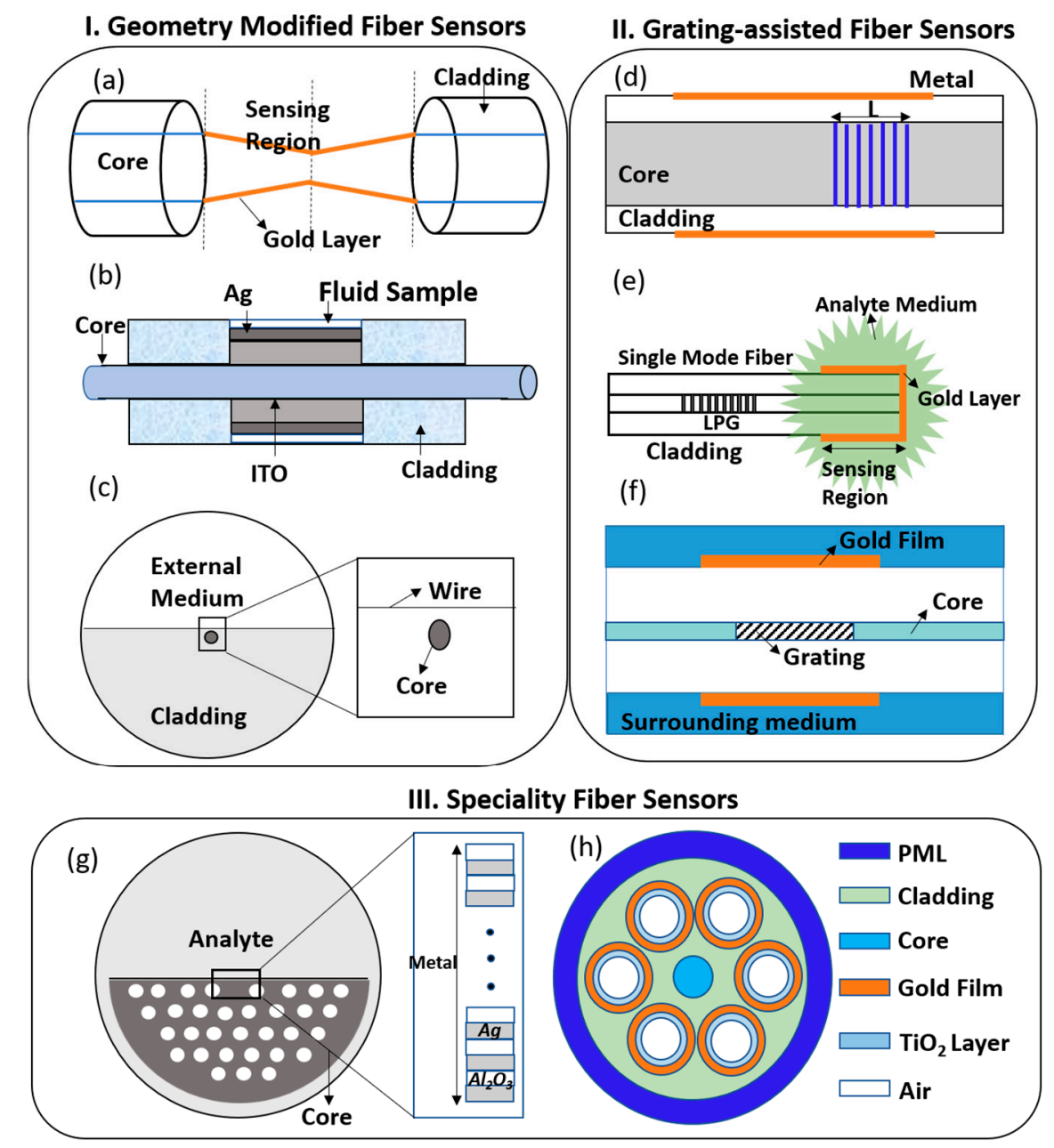

Figure 7. Schematic illustration of various geometries of SPR sensors. In I: $(\mathbf{a}-\mathbf{c})$ are conventional geometry modified fiber sensors [22,56,61]; In II: (d-f) are grating-assisted fiber sensors [66-68]; In III: $(\mathbf{g}-\mathbf{h})$ are specialty fiber sensors $[70,79]$.

Furthermore, polymer plastic MOFs have been used for plasmonic generation in achieving the biocompatibility [80]. The U-shaped plastic optical fiber (POF) with long period grating exhibits better sensing performance of $1130 \%$ / RIU with a resolution of $8.44 \times 10^{-4}$ in the RI range of 1.33 to 1.41 [81].

\subsection{Novel Techniques for Optical Fiber Sensors}

With the new developments in fiber fabrication, novel SPR sensors using optical fibers were reported in the last few years. In 2001, both magnesium fluoride and Teflon AF-1600 were successfully utilized as dielectric buffer materials for long-range surface plasmons (LRSPR) wavelength-modulated sensor design by Nenninger with a maximum sensitivity of $9200 \mathrm{~nm} /$ RIU [82]. In 2004, Chien and Chenb presented an improved theoretical analysis method for the LRSPR device by taking the angular interrogation into account, in addition to the spectral interrogation that is usually considered for the conventional SPR configuration [83]. In the same year, Ekgasit et al. explained their SPR spectroscopy experiment using the characteristic matrix approach and the total transmission coefficients [84]. Later on, the SPR imaging (SPRI) technique became the most promising tool for high-throughput detection and Corn's group reported SPR imaging with a special multilayer structure in 2005 [85]. A review of thin metal strip waveguides for LRSPR and their applications was presented by Berini in 2009 [86]. Further, Yashunsky et al. reported the existence of multiple phases in epithelial cell adhesion and showed that the penetration depth and propagation length of near-infrared SPR can be enhanced to more than $1 \mathrm{~mm}$ [87]. Abbas summarized new sensing materials, such as negative index materials, 
$\mathrm{ZnO}$, and other analytical techniques combined with SPR, in his review paper [88]. In 2017, Watad et al. proposed a spectro-polarimetric SPR sensor with high RI resolution and high tolerance that depends on the Ag film thickness [89]. CNT/Cu-nanoparticles with good dielectric properties were used for the design of a highly sensitive fiber SPR sensor based on the nanocomposite technique for the sensing of nitrates [90]. Recently, a review article by Abdulhalim discussed different configurations for high-performance sensors via an extended surface electromagnetic wave (SEW) [91]. Moreover, cholesterol oxidase was employed as a sensing material in FOPS for measuring the concentration of cholesterol by Gupta's group [92].

To date, the conventional coating methods of SPR-based FOPS have been reported based on RF sputtering, thermal evaporation, electrolysis plating or wet-chemistry deposition, and chemical vapor deposition. There is no unanimously recognized method to list the characteristics influencing sensor performance. However, sensitivity, resolution, and detection limit are considered to be a few important parameters that characterize the performance of the sensor. Hence, the sensor performance of recent SPR-based FOPS has to be compared with standard prism-based systems, which are bulkier and costlier.

\section{Concept of Surface Plasmon Resonance Biosensing}

In a FOPS detection process for biosensing, first, light needs to be launched through an optical fibre coated by a thin layer of noble metal. Then the evanescent wave propagates along the silica-metal interface and the maximum energy transfer from light to SPW occurs on the metal surface when its propagation constant is the same as that of SPW. The propagation constant of the SPW is extremely sensitive to the changes of the refractive index of the sample on the metal surface. Figure 8 illustrates an overview of the detection mechanism of a FOPS for antibody-antigen binding. The antibody elements initially immobilize themselves on the metal surface and then the interaction between the antibody and antigen results in the refractive index change of the samples, which can lead to a shift in the resonance wavelength of the FOPS. This significant wavelength shift caused by the binding introduces the changes in the refractive index that can be detected by a precise optical spectrometer [93].

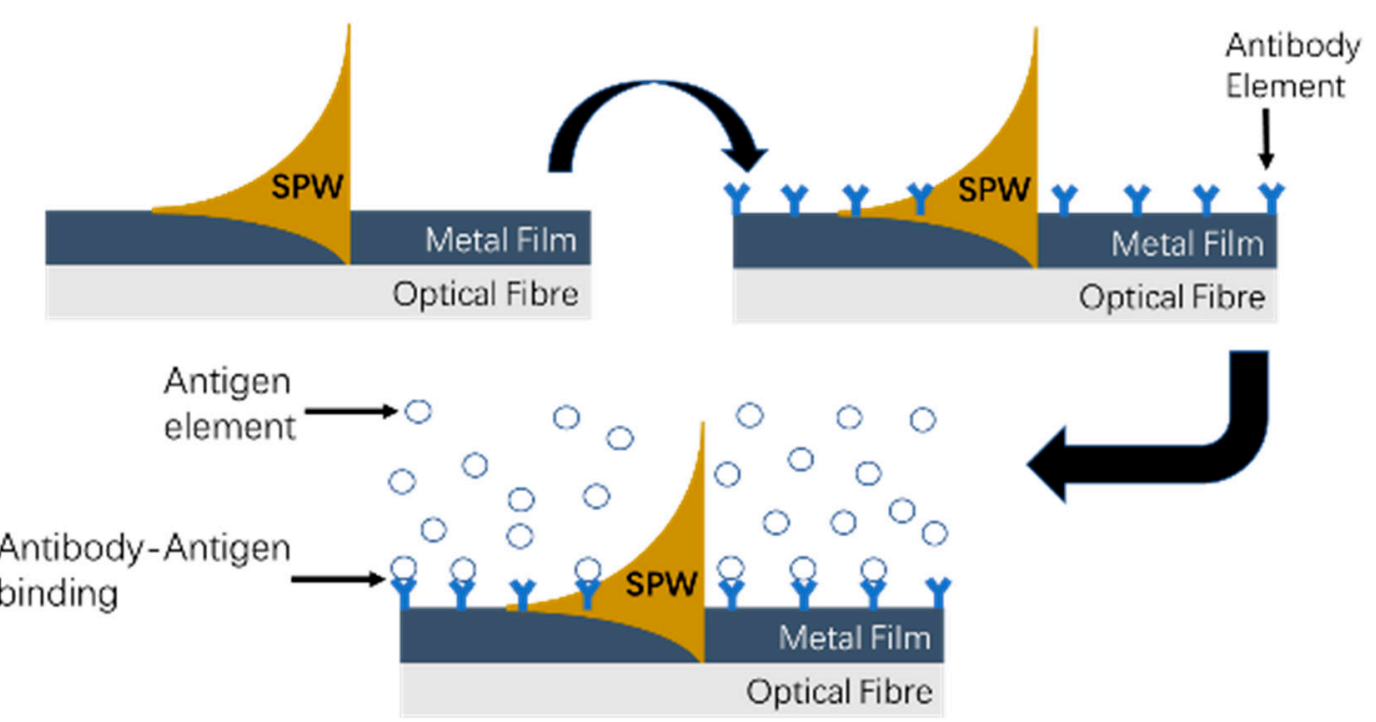

Figure 8. The detection mechanism based on FOPS for antibody-antigen binding process [92].

\section{Applications}

FOPS-based SPR sensors have brought several advantages, namely, minimum measurement of sample volumes, possibility of multi-sensing, geometric feasibility, miniaturization of the sensing device, and immunity to the electric signal noise of the sensing system [94]. The development and investigation of the biosensors have been reviewed and reported [38,45,95]. SPR-based FOPS have 
applications in biology and medicine. They can generally be classified into two groups, chemical sensors and biological sensors. The chemical sensors are "miniaturized analytical devices that can deliver real-time and on-line information in the presence of specific compounds or ions in complex samples," as defined by Wolfbeis [96]. A biosensor is an analytical device that converts the analyte into an electrical signal through the bio-recognition system with a transducer [97]. A range of biosensors for the detection of different biological samples are reviewed and tabulated in Table 1. It provides details of the sensor configuration with an application and the specific technique used for binding the functional materials, sample range used, and sensor performances. It includes both SPR and LSPR implementations in the reviewed sensor configurations. The SPR-based sensor devices operate in the visible region. Recently, an ITO-based SPR sensor has been established to operate in the near-infrared region. To model a sensor device in the near-infrared regime, the nanoparticle coating is incorporated in the sensor configuration, which further improves the optical properties [98].

\subsection{Medicine}

In cancer research, biosensors are used to analyze changes in the protein contents of cells [99]. Cancer cells use the body's energy and cause a change in how food energy is utilized in the human body. When these cancer cells are multiplied, they give impulse to adjoining organs, nerves and blood vessels, etc., [100]. In biomedical treatment, human fluids such as blood, tears, saliva, and urine can be used as an analyte in which different components of the chosen analyte can be analyzed [101]. In diabetic patients, monitoring the glucose level with blood as a sample causes uneasiness. As an alternative, tears can be used as an analyte in which the glucose level is 50 to 100 times lower than that of blood [102]. For every disease, earlier detection significantly improves the chances of a cure. Conventional techniques for detecting diseases are time-consuming. Additionally, to detect the disease requires a lot of expensive equipment. In recent years, researchers have found that these current biosensors are cost-effective and take less time compared with the conventional techniques. These biosensors are defining nano- or micro-fabrication technologies and the use of optical, electrical, and mechanical transducers.

\subsection{Food Safety}

Food safety will prevent an increase in foodborne diseases. The attention to handling, preparing, and preserving the food in conventional methods is tedious and time-consuming. The optical biosensors provide specificity, ease, and a fast response. The greater potential of optical biosensors lies in the detection of toxic substances in food. Recently, SPR optical biosensors have been developed for the detection of pesticide residues, veterinary drugs in animal-derived products, microbial contamination and hygienic monitoring, heavy metal adulterants, and other toxic compounds [103]. The most beneficial applications in optical biosensors consist of biological analytes and the analysis of biomolecular interactions [93]. Recently, the research and development of SPR-based FOPS in the area of drug discovery have been established for food safety [104]. Wan et al. simplified a protocol based on LSPR with enhanced sensitivity by embedding a gold nanoparticles thin film in the geometrical configuration of the biosensor [105]. The SPR-based biosensor's advancement towards multiplexing and coupling this advancement with biotechnology for high quality food safety assessment were reviewed [106]. Features of SPR-based optical biosensors used for pathogen detection in meat products were enumerated [107]. A new approach to blood glucose sensing with enhanced sensitivity of $0.0366 \mathrm{~nm} /(\mathrm{mg} / \mathrm{dL})$ has been established [108]. Recently, a novel glucose fiber optic grating sensor for the applications in food safety, disease diagnosis, and clinical analysis has been reported with high sensitivity of $0.298 \mathrm{~nm}(\mathrm{mg} / \mathrm{mL})^{-1}$ in low analyte concentrations of $0 \sim 3 \mathrm{mg} / \mathrm{mL}$ [109]. These SPR-based FOPS developed for food safety and quality assurance also satisfy the quality standards of international trade. SPR-based biosensors have resulted in great attention to the development of new techniques for predicting the internal quality parameters of food materials. 


\subsection{Environmental Monitoring}

Sensitivity monitoring of environmental pollutants, namely, pesticides, biological pollutants, disruptive chemicals, explosives, and toxins, is needed to safeguard environmental quality and therefore human health. To surpass the conventional chromatographic and spectroscopic technologies, which quantify the contamination in an environment with sophisticated instruments, a recently developed biosensor can be used for its simple protocols and cost-effectiveness. The functional biorecognition is a key concept of biosensors. Antibodies such as enzymes, antigens, aptamers, and DNAzyme are recurrently used as biorecognition molecules in optical fiber sensor technologies. A highly sensitive optical biosensor for interaction among environmental molecules with the sensitivity of $100 \mathrm{pg} / \mathrm{mL}$ has been reported [110]. Recently, a whole cell-based optical biosensor for detecting organic waste with a sensitivity of $0.74 \mu \mathrm{g} / \mathrm{L}$ was reported [111]. The applications of cell-based optical biosensors for environmental analysis and medical diagnostics were reviewed [112]. The environmental investigation requires more attention to diverse environmental phenomena including the fate and transport of contaminants. The other applications of the SPR-based FOBS are tabulated in Table 1 as follows:

Table 1. Summary of selected experimental performances for fiber optic plasmonic probes.

\begin{tabular}{|c|c|c|c|c|}
\hline $\begin{array}{c}\text { Sensor Configuration and Its } \\
\text { Application }\end{array}$ & $\begin{array}{c}\text { Operating } \\
\text { Wavelength (nm) }\end{array}$ & Functional Materials & $\begin{array}{l}\text { Performance with Sample } \\
\text { Range }\end{array}$ & Ref. \\
\hline $\begin{array}{l}\text { Etched optical fiber for detection of } \\
\text { salinity concentration }\end{array}$ & $1400-1600$ & $\begin{array}{c}\text { SMF + MMF + SMF coated } \\
\text { with ITO }\end{array}$ & $\begin{array}{l}7000 \mathrm{~nm} / \text { RIU for RI ranges } \\
\text { from } 1.333 \text { to } 1.338 .\end{array}$ & [113] \\
\hline $\begin{array}{l}\text { Symmetrically-etched POF sensor for } \\
\text { RI sensing application }\end{array}$ & $350-1100$ & Etched POF coated with Au & $\begin{array}{l}1600 \mathrm{~nm} / \mathrm{RIU} \text { for RI ranges } \\
\text { from } 1.3353 \text { to } 1.3453 \text {. } \\
1.257 \mathrm{~nm} / \mathrm{RIU} \text { for }\end{array}$ & [114] \\
\hline $\begin{array}{l}\text { Etched-optical fiber Bragg grating for } \\
\text { sensing deionized water and saline }\end{array}$ & $400-1600$ & $\begin{array}{l}\text { Etched D-shaped fiber Bragg } \\
\text { grating coated with } \mathrm{TiO}_{2}\end{array}$ & $\begin{array}{l}\text { air-deionized water and } \\
0.857 \mathrm{~nm} / \mathrm{RIU} \text { for air-saline } \\
\text { for the corresponding RI } 1 \\
\text { and } 1.318 .\end{array}$ & [115] \\
\hline $\begin{array}{l}\text { Tilted fiber Bragg grating sensor for } \\
\text { detecting urinary protein variations }\end{array}$ & $1440-1540$ & $\begin{array}{l}\text { Tilted fiber Bragg grating } \\
\text { coated with Ag }\end{array}$ & $\begin{array}{l}8000 \mathrm{~dB} / \text { RIU for RI ranges } \\
\text { from } 1.3400 \text { to } 1.3408\end{array}$ & [116] \\
\hline $\begin{array}{l}\text { Tapered fiber SPR-based sensing } \\
\text { systems for remote measurement of } \\
\text { chemical and biological parameters }\end{array}$ & $450-1700$ & $\underset{\text { fiber }}{\mathrm{Cr}+\mathrm{Au}+\mathrm{TiO}_{2} \text { coated on }}$ & $\begin{array}{c}5000 \mathrm{~nm} / \mathrm{RIU} \text { at } 1500 \mathrm{~nm} \text { for } \\
\mathrm{RI} \text { ranges from } 1.332 \text { to } \\
1.338 .\end{array}$ & [117] \\
\hline $\begin{array}{l}\text { Tapered multimode fiber sensor for RI } \\
\text { detection sensors }\end{array}$ & $400-1200$ & $\mathrm{Ag}+\mathrm{Au}$ coated on fiber & $\begin{array}{l}10 \text { times as compared to the } \\
\text { symmetric fiber sensing } \\
\text { probe for RI ranges from } \\
1.333-1.353\end{array}$ & [118] \\
\hline $\begin{array}{l}\text { Adiabatic tapered optical fiber sensor } \\
\text { for biochemical sensing }\end{array}$ & $400-2000$ & Tapered optical fiber $+\mathrm{TiO}_{2}$ & $\begin{array}{l}7096 \mathrm{~nm} / \text { RIU for RI ranges } \\
\text { from } 1.3373 \text { to } 1.3500\end{array}$ & [119] \\
\hline $\begin{array}{l}\text { Side polished single } \\
\text { mode-multimode-single mode fiber } \\
\text { for sensing characteristics }\end{array}$ & $1450-1610$ & $\begin{array}{l}\mathrm{SMF}+\mathrm{MMF}+\mathrm{SMF} 30 \mathrm{~mm} \\
35 \mathrm{~mm}, 40 \mathrm{~mm} \text {, and } 45 \mathrm{~mm}\end{array}$ & $\begin{array}{c}\text { The highest sensitivity of } 65 \\
\mathrm{~nm} / \mathrm{RIU} \text { in RI range from } \\
1.33 \text { to } 1.39 \text {, and of } 1190 \\
\mathrm{~nm} / \mathrm{RIU} \text { in RI range from } \\
1.43 \text { to } 1.45 .\end{array}$ & [120] \\
\hline $\begin{array}{l}\text { Side-polished plastic optical fiber for } \\
\text { biochemical application }\end{array}$ & $400-1100$ & $\begin{array}{c}\mathrm{Ag}+\text { silicon }+ \\
\text { Polyacrylamide Gel with } \\
\text { uricase enzyme }\end{array}$ & $\begin{array}{l}10.50 \mathrm{~nm} / \mathrm{mM} \text { in the range } \\
0-0.9 \mathrm{mM}\end{array}$ & [121] \\
\hline $\begin{array}{c}\text { Side-polished single-mode fiber for } \\
\text { the detection of Legionella } \\
\text { pneumophila }\end{array}$ & $400-1800$ & $\begin{array}{l}\mathrm{Au}+\mathrm{SAM}+\text { antigen } \mathrm{LP} \\
\quad \text { coated on fiber }\end{array}$ & $\begin{array}{l}\text { Legionella pneumophila } \\
\text { LOD } 10^{1} \mathrm{CFU} / \mathrm{ml}\end{array}$ & [122] \\
\hline
\end{tabular}


Table 1. Cont.

\begin{tabular}{|c|c|c|c|c|}
\hline $\begin{array}{c}\text { Sensor Configuration and Its } \\
\text { Application }\end{array}$ & $\begin{array}{c}\text { Operating } \\
\text { Wavelength (nm) }\end{array}$ & Functional Materials & $\begin{array}{l}\text { Performance with Sample } \\
\text { Range }\end{array}$ & Ref. \\
\hline $\begin{array}{l}\text { Coreless side-polished fiber for } \\
\text { multimode interference and refractive } \\
\text { index sensors }\end{array}$ & $1100-1650$ & $\begin{array}{c}\text { lead in SMF, transitional } \\
\text { section } \\
\text { 1, coreless flat section, } \\
\text { transitional section } \\
\text { 2, and lead-out SMF }\end{array}$ & $\begin{array}{l}15,666 \mathrm{~nm} / \mathrm{RIU} \text { in SRI range } \\
\text { from } 1.438 \text { to } 1.444\end{array}$ & [123] \\
\hline $\begin{array}{l}\text { Ag NP-based LSPR optical fiber } \\
\text { biosensor for detecting the } \\
\text { anti-human IgG }\end{array}$ & $200-800$ & $\begin{array}{l}\text { Human IgG + immobilized } \\
\text { on the sensor probe }\end{array}$ & $\begin{array}{l}387 \mathrm{~nm} / \mathrm{RIU} \text { for RI ranges } \\
\text { from } 1.33 \text { to } 1.40 .\end{array}$ & [124] \\
\hline $\begin{array}{c}\text { D-shaped fiber SPR-based plasmonic } \\
\text { sensor }\end{array}$ & $500-1200$ & Au coated on fiber & $\begin{array}{l}7381 \mathrm{~nm} / \mathrm{RIU} \text { for RI ranges } \\
\text { from } 1.40 \text { to } 1.42 .\end{array}$ & [125] \\
\hline $\begin{array}{c}\text { D-shaped fiber SPR-based plasmonic } \\
\text { sensor }\end{array}$ & $1000-1100$ & ITO coated on fiber & $\begin{array}{l}6000 \mathrm{~nm} \text { RIU for RI ranges } \\
\text { from } 1.30 \text { to } 1.31\end{array}$ & [126] \\
\hline D-shaped fiber SPR-based biosensor & $500-1720$ & $\mathrm{Au}+\mathrm{TiO}_{2}$ coated on fiber & $\begin{array}{l}46,000 \mathrm{~nm} / \mathrm{RIU} \text { at } 1130 \mathrm{~nm} \\
\text { for RI ranges from } 1.34 \text { to } \\
1.35 .\end{array}$ & [127] \\
\hline $\begin{array}{c}\text { U-bent fiber optic SPR sensor for } \\
\text { medicine, biotechnology and food } \\
\text { safety }\end{array}$ & $300-800$ & $\begin{array}{l}\text { Ag NPs coated on U-bent } \\
\text { optical fiber }\end{array}$ & $\begin{array}{l}1198 \mathrm{~nm} / \mathrm{RIU} \text { for RI ranges } \\
\text { from } 1.3657 \text { to } 1.3557 .\end{array}$ & [128] \\
\hline $\begin{array}{c}\text { PCF biosensor for biological analyte } \\
\text { detection }\end{array}$ & $500-740$ & $\begin{array}{l}\text { Au coated outside of the } \\
\text { PCF structure }\end{array}$ & $\begin{array}{l}2200 \mathrm{~nm} / \mathrm{RIU} \text { for RI ranges } \\
\text { from } 1.33 \text { to } 1.36 .\end{array}$ & [129] \\
\hline $\begin{array}{l}\text { Side-polished D-shaped PCF for } \\
\text { bio-chemical detection }\end{array}$ & $500-900$ & $\begin{array}{l}\text { Ag-coated side-polished } \\
\text { hexagonal structure PCF }\end{array}$ & $\begin{array}{l}21,700 \mathrm{~nm} / \mathrm{RIU} \text { for RI ranges } \\
\text { from } 1.33 \text { to } 1.34\end{array}$ & {$[130]$} \\
\hline $\begin{array}{l}\text { LSPR-based optical fiber sensor for RI } \\
\text { measurements }\end{array}$ & 200-1100 & $\begin{array}{l}\text { Ag NPs are coated on } \\
\text { optical fiber }\end{array}$ & $\begin{array}{l}1933 \mathrm{~nm} / \mathrm{RIU} \text { for } 1.333 \text { to } \\
1.404\end{array}$ & [131] \\
\hline $\begin{array}{l}\text { U-bent plastic optical fiber sensor for } \\
\text { biosensing }\end{array}$ & $300-800$ & $\begin{array}{l}\text { Ag thin film was deposited } \\
\text { on U-bent optical fiber }\end{array}$ & $\begin{array}{l}700.3 \mathrm{~nm} / \mathrm{RIU} \text { for ranges } \\
\text { from } 1.330 \text { to } 1.3657\end{array}$ & [132] \\
\hline
\end{tabular}

However, there are still some limitations to such SPR-based FOPS. For example, for the measurement of some physical parameters, such as curvature and displacement, the applications of the fiber optic SPR sensor are still limited because it is difficult to control the propagation angle of the light beam in the fiber and the intensity of the evanescent wave [134].

This review also provides the basis of fabrication techniques of SPR-based FOPS such as stack and draw method [135], drilling [136], sol-gel casting [137], slurry casting [138], and extrusion method [139]. The conventional stack and draw method is generally used to fabricate PCF-based SPR FOPS with the least transmission loss of $0.18 \mathrm{~dB} / \mathrm{km}$ at $1550 \mathrm{~nm}$ wavelength [140]. In every MOF-based FOPS, the complexity of the geometric structure is the most common issue. However, the fabrication of the asymmetric geometry of the sensor is a challenging process. Moreover, the metal coating on the surface of circular air holes in MOF-based sensors is one of the common difficulties that restrict the experimental realization of FOPS. Table 2 provides the various metal coating techniques such as sputtering, side-polishing, dip-coating, thermal evaporation, electroless plating, wet-chemistry deposition, and chemical vapor deposition. By using the chemical vapor deposition technique, the complex metal coating on the surface of the circular air holes has been reported [141,142]. Furthermore, the metal coating in the inner surface of the circular air holes is achieved by Tollens' reaction [143,144]. Among the various metal-coating techniques, the chemical method is the most common and is cost-effective. The self-calibration process is essential to characterize and utilize the sensor. Various analytes have been tested by exchanging with water and filling the nitrogen gas [143]. The fabrication approaches employed for the fabrication of SPR-based FOBS have been reported [15]. In practical applications, several SPR-based FOBS play a role in the chemical, biological. and medical fields. In 2015, a fast bioassay for determining the infliximab concentration in serum using an in-house developed SPR-based FOBS was reported [145]. In 2018, a red-green dual color SPR-based FOBS using a smartphone was developed for real-time biodetection by monitoring the binding of IgG and protein A [146]. These portable devices are attractive for point-of-care and remote detection of biomedical and environmental targets. In lab-on-fiber technology, a new vision for chemical and biological sensing has been proposed to determine the direct impact of localized cancer treatment [9]. On account of these developments, we believe that these SPR-based FOBS would contribute greatly to enhancing industrial applications in several areas of the physical, chemical, biological, and medical fields. 
Table 2. Various metal-coating techniques in the different geometry of FPOS (Fiber Optic Plasmonic Sensor).

\begin{tabular}{|c|c|c|c|}
\hline Type of Metal Coating & Advantage & Disadvantage & FOPS Geometric Structure \\
\hline $\begin{array}{l}\text { Selective metal coating } \\
{[76]}\end{array}$ & $\begin{array}{l}\text { Analyte is filled in the } \\
\text { chosen air hole cell }\end{array}$ & $\begin{array}{l}\text { Metal coating is } \\
\text { challenging on the } \\
\text { circular air holes }\end{array}$ & \\
\hline $\begin{array}{l}\text { External metal coating } \\
{[50]}\end{array}$ & $\begin{array}{l}\text { Analyte is filled in the } \\
\text { external surface of the } \\
\text { fiber }\end{array}$ & $\begin{array}{l}\text { Different air hole sizes } \\
\text { are required. }\end{array}$ & \\
\hline $\begin{array}{l}\text { Internal nanowire filling } \\
\text { [133] }\end{array}$ & $\begin{array}{l}\text { Analyte is filled in the } \\
\text { nanowire }\end{array}$ & $\begin{array}{l}\text { Selective filling of air } \\
\text { hole in nano size is } \\
\text { challenging }\end{array}$ & \\
\hline Side-polished [125] & $\begin{array}{l}\text { A flow of analyte is } \\
\text { allowed at the outer } \\
\text { surface of the fiber }\end{array}$ & $\begin{array}{l}\text { A precise etching and } \\
\text { polishing exertion are } \\
\text { needed }\end{array}$ & \\
\hline Micro-fluidic slots [76] & $\begin{array}{l}\text { Various analytes can be } \\
\text { analyzed at the same } \\
\text { time }\end{array}$ & $\begin{array}{l}\text { Making the metal slots is } \\
\text { challenging }\end{array}$ & \\
\hline
\end{tabular}

\section{Conclusions and Future Directions}

In this paper, we have reviewed the theoretical model and experimental techniques that culminated in the successful realization of FOPS for biological applications. In this review, we have explained the SPR technique in different media, namely, prism-based SPR FOPS, grating-based SPR FOPS, and optical fiber-based SPR FOPS. Currently, the novel SPR-based FOPS geometries and approaches are being explored by several groups to model sensors for achieving high sensitivity and high resolution with better performance. It is noted that the optical fiber-based SPR FOPS are enormously attractive for the possibility of sensor miniaturization. Nowadays, the unique properties of the metal nanoparticles are used to explain the phenomenon of LSPR in FOPS. Several functionalization strategies for metal-based LSPR have been established. In this line, engineering the optical properties and thin-film thickness are carried for such lamellar SPR-based FOPS for point-of-care biosensing applications. 
Recent trends concerning several geometries of the FOPS have been discussed. We have found that the applications of FOPS in medical diagnosis, such as characteristics of particular biomolecular species, have been analyzed on buffered samples instead of clinical samples. With the SPR-based FOPS, the penetration depth is limited. Identifying a specific molecule among groups of molecules with less interaction between the unwanted molecules remains difficult. Besides high sensitivity and better performance, compactness is also a challenging task for future research. For the early detection of cancer and cardiovascular problems such as tissue perfusion, blood pressure, heart rate, etc., novel biosensors can be developed by exploiting the optical properties of recently proposed materials such as TMDC, hBN, black phosphorus, etc. Furthermore, new fiber designs may also be introduced for achieving low-cost biosensors. FOPS shall also be considered for understanding the role of several characterizations of optical fibers during the sensing process. Finally, we believe that this review will help encourage further research in the field of SPR-based FOPS.

Author Contributions: Conceptualization, All Authors; Methodology, All Authors; Software, M.S.A.G. and S.C.; Validation, K.S., P.R.B., K.N. and Q.L.; Formal Analysis, All Authors; Investigation, M.S.A.G. and S.C.; Resources, All Authors; Data Curation, M.S.A.G. and S.C.; Writing-Original Draft Preparation, M.S.A.G. and S.C.; Writing-Review and Editing, All Authors; Visualization, K.S., P.R.B., K.N. and Q.L.; Supervision, K.S., P.R.B., K.N. and Q.L.; Project Administration, K.N. and Q.L.; Funding Acquisition, K.N. and Q.L.

Funding: This research was funded by National Natural Science Foundation of China (NSFC), grant number [61675008].

Acknowledgments: KN wishes to thank The Royal Society Kan Tong Po International Fellowship 2018 for the travel fund to visit Hong Kong Polytechnic University and Shenzhen Science and Technology Innovation Commission (Project GJHZ20180411185015272).

Conflicts of Interest: The authors declare no conflict of interest.

\section{References}

1. Jorgenson, R.C.; Yee, S.S. A fiber-optic chemical sensor based on surface plasmon resonance. Sens. Actuators B Chem. 1993, 12, 213-220. [CrossRef]

2. Khan, M.; Kang, S.-W.; Khan, M.R.R.; Kang, S.-W. A high sensitivity and wide dynamic range fiber-optic sensor for low-concentration VOC gas detection. Sensors 2014, 14, 23321-23336. [CrossRef] [PubMed]

3. Yoo, W.J.; Jang, K.W.; Seo, J.K.; Moon, J.; Han, K.-T.; Park, J.-Y.; Park, B.G.; Lee, B.; Yoo, W.J.; Jang, K.W.; et al. Development of a 2-channel embedded infrared fiber-optic temperature sensor using silver halide optical fibers. Sensors 2011, 11, 9549-9559. [CrossRef] [PubMed]

4. Poeggel, S.; Tosi, D.; Duraibabu, D.; Leen, G.; McGrath, D.; Lewis, E.; Poeggel, S.; Tosi, D.; Duraibabu, D.; Leen, G.; et al. optical fibre pressure sensors in medical applications. Sensors 2015, 15, 17115-17148. [CrossRef] [PubMed]

5. Huang, Q.; Lee, J.; Arce, F.T.; Yoon, I.; Angsantikul, P.; Liu, J.; Shi, Y.; Villanueva, J.; Thamphiwatana, S.; Ma, X.; et al. Nanofibre optic force transducers with sub-piconewton resolution via near-field plasmon-dielectric interactions. Nat. Photonics 2017, 11, 352-355. [CrossRef] [PubMed]

6. Huston, A.L.; Justus, B.L.; Johnson, T.L. Fiber-optic-coupled, laser heated thermoluminescence dosimeter for remote radiation sensing. Appl. Phys. Lett. 1996, 68, 3377-3379. [CrossRef]

7. Yin, M.; Huang, B.; Gao, S.; Zhang, A.P.; Ye, X. Optical fiber LPG biosensor integrated microfluidic chip for ultrasensitive glucose detection. Biomed. Opt. Express 2016, 7, 2067-2077. [CrossRef] [PubMed]

8. Fiber-optic Sensors for Food Safety Monitoring by Ocean Optics. Available online: https:// www.bioopticsworld.com/articles/2011/12/fiber-optic-sensors-by-ocean-optics.html (accessed on 31 October 2018).

9. Ricciardi, A.; Crescitelli, A.; Vaiano, P.; Quero, G.; Consales, M.; Pisco, M.; Esposito, E.; Cusano, A. Lab-on-fiber technology: A new vision for chemical and biological sensing. Analyst 2015, 140, 8068-8079. [CrossRef] [PubMed]

10. Chiavaioli, F.; Baldini, F.; Tombelli, S.; Trono, C.; Giannetti, A. Biosensing with optical fiber gratings. Nanophotonics 2017, 6, 663-679. [CrossRef]

11. Wood, R.W. XLII. On a remarkable case of uneven distribution of light in a diffraction grating spectrum. Lond. Edinb. Dublin Philos. Mag. J. Sci. 1902, 4, 396-402. [CrossRef] 
12. Otto, A. Excitation of nonradiative surface plasma waves in silver by the method of frustrated total reflection. Z. Physik 1968, 216, 398-410. [CrossRef]

13. Raether, H. Surface plasmons on gratings. In Surface Plasmons on Smooth and Rough Surfaces and on Gratings; Raether, H., Ed.; Springer: Berlin/Heidelberg, Germany, 1988; pp. 91-116. ISBN 978-3-540-47441-8.

14. Pitarke, J.M.; Silkin, V.M.; Chulkov, E.V.; Echenique, P.M. Theory of surface plasmons and surface-plasmon polaritons. Rep. Prog. Phys. 2007, 70, 1. [CrossRef]

15. Gupta, B.D.; Srivastava, S.K.; Verma, R. Fiber Optic Sensors Based on Plasmonics; World Scientific: Singapore, 2014; ISBN 978-981-4619-54-7.

16. Venditti, I. Gold nanoparticles in photonic crystals applications: A review. Materials 2017, 10, 97. [CrossRef] [PubMed]

17. Kretschmann, E.; Raether, H. Notizen: Radiative decay of non radiative surface plasmons excited by light. Zeitschrift für Naturforschung A 2014, 23, 2135-2136. [CrossRef]

18. Leung, A.; Shankar, P.M.; Mutharasan, R. Real-time monitoring of bovine serum albumin at femtogram $/ \mathrm{mL}$ levels on antibody-immobilized tapered fibers. Sens. Actuators B Chem. 2007, 123, 888-895. [CrossRef]

19. Wen-xu, L.; Jian, C. Continuous monitoring of adriamycin in vivo using fiber optic-based fluorescence chemical sensor. Anal. Chem. 2003, 75, 1458-1462. [CrossRef] [PubMed]

20. Nath, N.; Jain, S.R.; Anand, S. Evanescent wave fibre optic sensor for detection of L. Donovani specific antibodies in sera of kala azar patients. Biosens. Bioelectron 1997, 12, 491-498. [CrossRef]

21. Ouyang, Q.; Zeng, S.; Jiang, L.; Hong, L.; Xu, G.; Dinh, X.-Q.; Qian, J.; He, S.; Qu, J.; Coquet, P.; et al. Sensitivity enhancement of transition metal dichalcogenides/silicon nanostructure-based surface plasmon resonance biosensor. Sci. Rep. 2016, 6, 28190. [CrossRef] [PubMed]

22. Mishra, A.K.; Mishra, S.K.; Gupta, B.D. SPR based fiber optic sensor for refractive index sensing with enhanced detection accuracy and figure of merit in visible region. Opt. Commun. 2015, 344, 86-91. [CrossRef]

23. Sharma, A.K.; Jha, R.; Gupta, B.D. Fiber-optic sensors based on surface plasmon resonance: A comprehensive review. IEEE Sens. J. 2007, 7, 1118-1129. [CrossRef]

24. Cennamo, N.; Massarotti, D.; Galatus, R.; Conte, L.; Zeni, L.; Cennamo, N.; Massarotti, D.; Galatus, R.; Conte, L.; Zeni, L. Performance comparison of two sensors based on surface plasmon resonance in a plastic optical fiber. Sensors 2013, 13, 721-735. [CrossRef] [PubMed]

25. Hassani, A.; Skorobogatiy, M. Design criteria for microstructured-optical-fiber-based surface-plasmon-resonance sensors. J. Opt. Soc. Am. B. 2007, 24, 1423-1429. [CrossRef]

26. Hlubina, P.; Kadulova, M.; Ciprian, D.; Sobota, J. Reflection-based fibre-optic refractive index sensor using surface plasmon resonance. J. Eur. Opt. Soc. Rapid Publ. 2014, 9, 1-5. [CrossRef]

27. Jian, A.; Deng, L.; Sang, S.; Duan, Q.; Zhang, X.; Zhang, W. Surface plasmon resonance sensor based on an angled optical fiber. IEEE Sens. J. 2014, 14, 3229-3235. [CrossRef]

28. Jian, A.Q.; Zhang, X.M. Resonant optical tunneling effect: recent progress in modeling and applications. IEEE J. Sel. Top. Quantum Electron. 2013, 19, 9000310. [CrossRef]

29. Kim, Y.-C.; Banerji, S.; Masson, J.-F.; Peng, W.; Booksh, K.S. Fiber-optic surface plasmon resonance for vapor phase analyses. Analyst 2005, 130, 838-843. [CrossRef] [PubMed]

30. Kim, Y.-C.; Peng, W.; Banerji, S.; Booksh, K.S. Tapered fiber optic surface plasmon resonance sensor for analyses of vapor and liquid phases. Opt. Lett. 2005, 30, 2218-2220. [CrossRef] [PubMed]

31. Suzuki, H.; Sugimoto, M.; Matsui, Y.; Kondoh, J. Effects of gold film thickness on spectrum profile and sensitivity of a multimode-optical-fiber SPR sensor. Sens. Actuators B Chem. 2008, 132, 26-33. [CrossRef]

32. Roh, S.; Chung, T.; Lee, B.; Roh, S.; Chung, T.; Lee, B. Overview of the characteristics of micro- and nano-structured surface plasmon resonance sensors. Sensors 2011, 11, 1565-1588. [CrossRef] [PubMed]

33. Fu, H.; Zhang, S.; Chen, H.; Weng, J. Graphene enhances the sensitivity of fiber-optic surface plasmon resonance biosensor. IEEE Sens. J. 2015, 15, 5478-5482. [CrossRef]

34. Mishra, A.K.; Mishra, S.K.; Verma, R.K. Graphene and beyond graphene MoS2: A new window in surface-plasmon-resonance-based fiber optic sensing. J. Phys. Chem. C 2016, 120, 2893-2900. [CrossRef]

35. Shushama, K.N.; Rana, M.M.; Inum, R.; Hossain, M.B. Graphene coated fiber optic surface plasmon resonance biosensor for the DNA hybridization detection: Simulation analysis. Opt. Commun. 2017, 383, 186-190. [CrossRef]

36. Rifat, A.A.; Mahdiraji, G.A.; Ahmed, R.; Chow, D.M.; Sua, Y.M.; Shee, Y.G.; Adikan, F.R.M. Copper-graphene-based photonic crystal fiber plasmonic biosensor. IEEE Photonics J. 2016, 8, 1-8. [CrossRef] 
37. Ritchie, R.H. Plasma losses by fast electrons in thin films. Phys. Rev. 1957, 106, 874-881. [CrossRef]

38. Liang, G.; Luo, Z.; Liu, K.; Wang, Y.; Dai, J.; Duan, Y. Fiber optic surface plasmon resonance-Based biosensor technique: Fabrication, advancement, and application. Crit. Rev. Anal. Chem. 2016, 46, 213-223. [CrossRef] [PubMed]

39. Petryayeva, E.; Krull, U.J. Localized surface plasmon resonance: Nanostructures, bioassays and biosensing-A review. Analytica Chimica Acta 2011, 706, 8-24. [CrossRef] [PubMed]

40. Gupta, B.D.; Kant, R. Recent advances in surface plasmon resonance based fiber optic chemical and biosensors utilizing bulk and nanostructures. Opt. Laser Technol. 2018, 101, 144-161. [CrossRef]

41. Caucheteur, C.; Guo, T.; Albert, J. Review of plasmonic fiber optic biochemical sensors: Improving the limit of detection. Anal. Bioanal. Chem. 2015, 407, 3883-3897. [CrossRef] [PubMed]

42. Zhou, C. Localized surface plasmonic resonance study of silver nanocubes for photonic crystal fiber sensor. Opt. Lasers Eng. 2012, 50, 1592-1595. [CrossRef]

43. Sciacca, B.; Monro, T.M. Dip biosensor based on localized surface plasmon resonance at the tip of an optical fiber. Langmuir 2014, 30, 946-954. [CrossRef] [PubMed]

44. Kretschmann, E. Decay of non radiative surface plasmons into light on rough silver films. Comparison of experimental and theoretical results. Opt. Commun. 1972, 6, 185-187. [CrossRef]

45. Wijaya, E.; Lenaerts, C.; Maricot, S.; Hastanin, J.; Habraken, S.; Vilcot, J.-P.; Boukherroub, R.; Szunerits, S. Surface plasmon resonance-based biosensors: From the development of different SPR structures to novel surface functionalization strategies. Curr. Opin. Solid State Mater. Sci. 2011, 15, 208-224. [CrossRef]

46. Gedig, E.T. Handbook of surface plasmon resonance. In Surface Chemistry in SPR Technology; Royal Society of Chemistry: London, UK, 2017; pp. 171-220. ISBN 978-1-78801-139-6.

47. Otupiri, R.; Akowuah, E.K.; Haxha, S. Multi-channel SPR biosensor based on PCF for multi-analyte sensing applications. Opt. Express 2015, 23, 15716-15727. [CrossRef] [PubMed]

48. Akowuah, E.K.; Gorman, T.; Ademgil, H.; Haxha, S.; Robinson, G.K.; Oliver, J.V. Numerical analysis of a photonic crystal fiber for biosensing applications. IEEE J. Quantum Electron. 2012, 48, 1403-1410. [CrossRef]

49. Rifat, A.A.; Mahdiraji, G.A.; Sua, Y.M.; Shee, Y.G.; Ahmed, R.; Chow, D.M.; Adikan, F.R.M. Surface plasmon resonance photonic crystal fiber biosensor: A practical sensing approach. IEEE Photonics Technol. Lett. 2015, 27, 1628-1631. [CrossRef]

50. Chakma, S.; Khalek, M.A.; Paul, B.K.; Ahmed, K.; Hasan, M.R.; Bahar, A.N. Gold-coated photonic crystal fiber biosensor based on surface plasmon resonance: Design and analysis. Sens. Bio Sens. Res. 2018, 18, 7-12. [CrossRef]

51. Chu, S.; Nakkeeran, K.; Abobaker, A.M.; Aphale, S.S.; Babu, P.R.; Senthilnathan, K. Design and analysis of surface-plasmon-resonance-based photonic quasi-crystal fiber biosensor for high-refractive-index liquid analytes. IEEE J. Sel. Top. Quantum Electron. 2019, 25, 1-9. [CrossRef]

52. Sherry, L.J.; Chang, S.-H.; Schatz, G.C.; Van Duyne, R.P.; Wiley, B.J.; Xia, Y. Localized surface plasmon resonance spectroscopy of single silver nanocubes. Nano Lett. 2005, 5, 2034-2038. [CrossRef] [PubMed]

53. Dwivedi, Y.S.; Sharma, A.K.; Gupta, B.D. Influence of design parameters on the performance of a surface plasmon sensor based fiber optic sensor. Plasmonics 2008, 3, 79-86. [CrossRef]

54. Gauvreau, B.; Hassani, A.; Fehri, M.F.; Kabashin, A.; Skorobogatiy, M. Photonic bandgap fiber-based surface plasmon resonance sensors. Opt. Express 2007, 15, 11413-11426. [CrossRef] [PubMed]

55. Wu, W.-T.; Jen, C.-P.; Tsao, T.-C.; Shen, W.-C.; Cheng, C.-W.; Chen, C.-H.; Tang, J.-L.; Li, W.-Y.; Chau, L.-K. U-shaped fiber optics fabricated with a femtosecond laser and integrated into a localized plasmon resonance biosensor. In Proceedings of the 2009 Symposium on Design, Test, Integration Packaging of MEMS/MOEMS, Rome, Italy, 1-3 April 2009; pp. 127-131.

56. Verma, R.K.; Sharma, A.K.; Gupta, B.D. Surface plasmon resonance based tapered fiber optic sensor with different taper profiles. Opt. Commun. 2008, 281, 1486-1491. [CrossRef]

57. Arregui, F.J.; Del Villar, I.; Corres, J.M.; Goicoechea, J.; Zamarreño, C.R.; Elosua, C.; Hernaez, M.; Rivero, P.J.; Socorro, A.B.; Urrutia, A.; et al. Fiber-optic lossy mode resonance sensors. Procedia. Eng. 2014, 87, 3-8. [CrossRef]

58. Wang, H.; Yan, X.; Li, S.; An, G.; Zhang, X.; Wang, H.; Yan, X.; Li, S.; An, G.; Zhang, X. High sensitivity refractive index sensor based on dual-core photonic crystal fiber with hexagonal lattice. Sensors 2016, 16, 1655. [CrossRef] [PubMed] 
59. Chilwell, J.; Hodgkinson, I. Thin-films field-transfer matrix theory of planar multilayer waveguides and reflection from prism-loaded waveguides. Nature 1984, 1, 742-753. [CrossRef]

60. Haddouche, I.; Cherbi, L.; Ferhat, M.L. Analytical modelization of a fiber optic-based surface plasmon resonance sensor. Opt. Commun. 2017, 402, 618-623. [CrossRef]

61. Santos, D.F.; Guerreiro, A.; Baptista, J.M. Surface plasmon resonance sensor based on D-type fiber with a gold wire. Optik 2017, 139, 244-249. [CrossRef]

62. Luan, N.; Wang, R.; Lv, W.; Lu, Y.; Yao, J.; Luan, N.; Wang, R.; Lv, W.; Lu, Y.; Yao, J. Surface plasmon resonance temperature sensor based on photonic crystal fibers randomly filled with silver nanowires. Sensors 2014, 14, 16035-16045. [CrossRef] [PubMed]

63. Villar, I.D.; Zubiate, P.; Zamarreño, C.R.; Arregui, F.J.; Matias, I.R. Optimization in nanocoated D-shaped optical fiber sensors. Opt. Express 2017, 25, 10743-10756. [CrossRef] [PubMed]

64. Qazi, H.H.; Mohammad, A.B.; Ahmad, H.; Zulkifli, M.Z.; Harun, S.W. Single-mode D-shaped optical fiber sensor for the refractive index monitoring of liquid. J. Mod. Opt. 2016, 63, 750-755. [CrossRef]

65. Chen, C.-H.; Tsao, T.-C.; Tang, J.-L.; Wu, W.-T.; Chen, C.-H.; Tsao, T.-C.; Tang, J.-L.; Wu, W.-T. A Multi-D-shaped optical fiber for refractive index sensing. Sensors 2010, 10, 4794-4804. [CrossRef] [PubMed]

66. Nemova, G.; Kashyap, R. Fiber-bragg-grating-assisted surface plasmon-polariton sensor. Opt. Lett. 2006, 31, 2118-2120. [CrossRef] [PubMed]

67. Schuster, T.; Herschel, R.; Neumann, N.; Schäffer, C.G. Miniaturized long-period fiber grating assisted surface plasmon resonance sensor. J. Lightwave Technol. 2012, 30, 1003-1008. [CrossRef]

68. Caucheteur, C.; Guo, T.; Liu, F.; Guan, B.-O.; Albert, J. Ultrasensitive plasmonic sensing in air using optical fibre spectral combs. Nat. Commun. 2016, 7, 13371. [CrossRef] [PubMed]

69. Piliarik, M.; Homola, J.; Maníková, Z.; Čtyroký, J. Surface plasmon resonance sensor based on a single-mode polarization-maintaining optical fiber. Sens. Actuators B Chem. 2003, 90, 236-242. [CrossRef]

70. Santos, D.F.; Guerreiro, A.; Baptista, J.M. SPR optimization using metamaterials in a D-type PCF refractive index sensor. Opt. Fiber Technol. 2017, 33, 83-88. [CrossRef]

71. Luan, N.; Wang, R.; Lv, W.; Yao, J. Surface plasmon resonance sensor based on D-shaped microstructured optical fiber with hollow core. Opt. Express 2015, 23, 8576-8582. [CrossRef] [PubMed]

72. Liu, Z.; Tam, H.-Y.; Htein, L.; Tse, M.-L.V.; Lu, C. Microstructured optical fiber sensors. J. Lightwave Technol. 2017, 35, 3425-3439. [CrossRef]

73. Rindorf, L.; Jensen, J.B.; Dufva, M.; Pedersen, L.H.; Høiby, P.E.; Bang, O. Photonic crystal fiber long-period gratings for biochemical sensing. Opt. Express 2006, 14, 8224-8231. [CrossRef] [PubMed]

74. Moore, J.P.; Rogge, M.D. Shape sensing using multi-core fiber optic cable and parametric curve solutions. Opt. Express 2012, 20, 2967-2973. [CrossRef] [PubMed]

75. Knight, J.C.; Birks, T.A.; Mangan, B.J.; Russel, P.S.J.; Vienne, G.G.; Sandro, J.-P.D. Multicore photonic crystal fibres. In Proceedings of the 12th International Conference on Optical Fiber Sensors, Williamsburg, VA, USA, 28-31 October 1997; Optical Society of America: Washington, WA, USA, 1997; p. PDP5.

76. Hassani, A.; Skorobogatiy, M. Design of the microstructured optical fiber-based surface plasmon resonance sensors with enhanced microfluidics. Opt. Express 2006, 14, 11616-11621. [CrossRef] [PubMed]

77. Lu, Y.; Hao, C.-J.; Wu, B.-Q.; Huang, X.-H.; Wen, W.-Q.; Fu, X.-Y.; Yao, J.-Q.; Lu, Y.; Hao, C.-J.; Wu, B.-Q.; et al. Grapefruit fiber filled with silver nanowires surface plasmon resonance sensor in aqueous environments. Sensors 2012, 12, 12016-12025. [CrossRef] [PubMed]

78. Wong, W.C.; Chan, C.C.; Boo, J.L.; Teo, Z.Y.; Tou, Z.Q.; Yang, H.B.; Li, C.M.; Leong, K.C. Photonic crystal fiber surface plasmon resonance biosensor based on protein $\mathrm{G}$ immobilization. IEEE J. Sel. Top. Quantum Electron. 2013, 19, 4602107. [CrossRef]

79. Gao, D.; Guan, C.; Wen, Y.; Zhong, X.; Yuan, L. Multi-hole fiber based surface plasmon resonance sensor operated at near-infrared wavelengths. Opt. Commun. 2014, 313, 94-98. [CrossRef]

80. Cennamo, N.; D’Agostino, G.; Donà, A.; Dacarro, G.; Pallavicini, P.; Pesavento, M.; Zeni, L.; Cennamo, N.; D'Agostino, G.; Donà, A.; et al. Localized surface plasmon resonance with five-branched gold nanostars in a plastic optical fiber for bio-chemical sensor implementation. Sensors 2013, 13, 14676-14686. [CrossRef] [PubMed]

81. Teng, C.; Yu, F.; Ding, Y.; Zheng, J. Refractive index sensor based on multi-mode plastic optical fiber with long period grating. In Proceedings of the Optical Sensors, New Orleans, LA, USA, 24-27 July 2017; International Society for Optics and Photonics: Bellingham, WA, USA, 2017; Volume 10231, p. 102311. 
82. Nenninger, G.G.; Tobiška, P.; Homola, J.; Yee, S.S. Long-range surface plasmons for high-resolution surface plasmon resonance sensors. Sens. Actuators B Chem. 2001, 74, 145-151. [CrossRef]

83. Chien, F.-C.; Chen, S.-J. A sensitivity comparison of optical biosensors based on four different surface plasmon resonance modes. Biosens. Bioelectron. 2004, 20, 633-642. [CrossRef] [PubMed]

84. Ekgasit, S.; Thammacharoen, C.; Knoll, W. Surface plasmon resonance spectroscopy based on evanescent field treatment. Anal. Chem. 2004, 76, 561-568. [CrossRef] [PubMed]

85. Wark, A.W.; Lee, H.J.; Corn, R.M. Long-range surface plasmon resonance imaging for bioaffinity sensors. Anal. Chem. 2005, 77, 3904-3907. [CrossRef] [PubMed]

86. Berini, P. Long-range surface plasmon polaritons. Adv. Opt. Photon. 2009, 1, 484-588. [CrossRef]

87. Yashunsky, V.; Lirtsman, V.; Golosovsky, M.; Davidov, D.; Aroeti, B. Real-time monitoring of epithelial cell-cell and cell-substrate interactions by infrared surface plasmon spectroscopy. Biophys. J. 2010, 99, 4028-4036. [CrossRef] [PubMed]

88. Abbas, A.; Linman, M.J.; Cheng, Q. New trends in instrumental design for surface plasmon resonance-based biosensors. Biosens. Bioelectron. 2011, 26, 1815-1824. [CrossRef] [PubMed]

89. Watad, I.; Abdulhalim, I. Comparative study between polarimetric and intensity-based surface plasmon resonance sensors in the spectral mode. Appl. Opt. 2017, 56, 7549-7558. [CrossRef] [PubMed]

90. Parveen, S.; Pathak, A.; Gupta, B.D. Fiber optic SPR nanosensor based on synergistic effects of CNT/Cu-nanoparticles composite for ultratrace sensing of nitrate. Sens. Actuators B Chem. 2017, 246, 910-919. [CrossRef]

91. Abdulhalim, I. Coupling configurations between extended surface electromagnetic waves and localized surface plasmons for ultrahigh field enhancement. Nanophotonics 2018, 7, 1891-1916. [CrossRef]

92. Semwal, V.; Gupta, B.D. LSPR- and SPR-based fiber-optic cholesterol sensor using immobilization of cholesterol oxidase over silver nanoparticles coated graphene oxide nanosheets. IEEE Sens. J. 2018, 18, 1039-1046. [CrossRef]

93. Homola, J. Present and future of surface plasmon resonance biosensors. Anal. Bioanal. Chem. 2003, 377, 528-539. [CrossRef] [PubMed]

94. Consales, M.; Ricciardi, A.; Crescitelli, A.; Esposito, E.; Cutolo, A.; Cusano, A. Lab-on-fiber technology: Toward multifunctional optical nanoprobes. ACS Nano 2012, 6, 3163-3170. [CrossRef] [PubMed]

95. Gupta, B.D.; Verma, R.K. Surface plasmon resonance-based fiber optic sensors: Principle, probe designs, and some applications. J. Sens. 2009, 2009, 12. [CrossRef]

96. Wolfbeis, O.S.; Weidgans, B.M. Fiber optic chemical sensors and biosensors: A view back. In Proceedings of the Optical Chemical Sensors; Baldini, F., Chester, A.N., Homola, J., Martellucci, S., Eds.; Springer: Dordrecht, The Netherlands, 2006; pp. 17-44.

97. Yin, S.; Ruffin, P. Fiber optic sensors. In Wiley Encyclopedia of Biomedical Engineering; American Cancer Society: Atlanta, GA, USA, 2006; ISBN 978-0-471-74036-0.

98. Urrutia, A.; Goicoechea, J.; Arregui, F.J. Optical fiber sensors based on nanoparticle-embedded coatings. J. Sens. 2015. [CrossRef]

99. Sharma, P.; Sharan, P.; Deshmukh, P. A photonic crystal sensor for analysis and detection of cancer cells. In Proceedings of the 2015 International Conference on Pervasive Computing (ICPC), Pune, India, 8-10 January 2015; pp. 1-5.

100. American Cancer Society. Cancer Facts \& Figures 2016. Available online: https://www.cancer.org/content/ dam/cancer-org/research / cancer-facts-and-statistics/annual-cancer-facts-and-figures/2016/cancerfacts-and-figures-2016.pdf (accessed on 31 October 2018).

101. Chopra, H.; Kaler, R.S.; Painam, B. Photonic crystal waveguide-based biosensor for detection of diseases. J. Nanophotonics 2016, 10, 036011. [CrossRef]

102. Zhang, J.; Hodge, W.; Hutnick, C.; Wang, X. Noninvasive diagnostic devices for diabetes through measuring tear glucose. J. Diabetes Sci Technol. 2011, 5, 166-172. [CrossRef] [PubMed]

103. Narsaiah, K.; Jha, S.N.; Bhardwaj, R.; Sharma, R.; Kumar, R. Optical biosensors for food quality and safety assurance-A review. J. Food Sci Technol. 2012, 49, 383-406. [CrossRef] [PubMed]

104. Cooper, M.A. Optical biosensors in drug discovery. Nat. Rev. Drug Discov. 2002, 1, 515-528. [CrossRef] [PubMed] 
105. Wan, M.; Luo, P.; Jin, J.; Xing, J.; Wang, Z.; Wong, S.T.C.; Wan, M.; Luo, P.; Jin, J.; Xing, J.; et al. Fabrication of localized surface plasmon resonance fiber probes using ionic self-assembled gold nanoparticles. Sensors 2010, 10, 6477-6487. [CrossRef] [PubMed]

106. Situ, C.; Mooney, M.H.; Elliott, C.T.; Buijs, J. Advances in surface plasmon resonance biosensor technology towards high-throughput, food-safety analysis. TrAC Trends Anal. Chem. 2010, 29, 1305-1315. [CrossRef]

107. Narsaiah, K.; Jha, S.N. Nondestructive methods for quality evaluation of livestock products. J. Food Sci. Technol. 2012, 49, 342-348. [CrossRef] [PubMed]

108. Srivastava, S.K.; Verma, R.; Gupta, B.D. Surface plasmon resonance based fiber optic glucose biosensor. In Proceedings of the Third Asia Pacific Optical Sensors Conference, International Society for Optics and Photonics, Sidney, Australia, 31 January-3 February 2012; Volume 8351, p. 83511Z.

109. Luo, B.; Yan, Z.; Sun, Z.; Li, J.; Zhang, L. Novel glucose sensor based on enzyme-immobilized $81^{\circ}$ tilted fiber grating. Opt. Express 2014, 22, 30571-30578. [CrossRef] [PubMed]

110. Piliarik, M.; Bocková, M.; Homola, J. Surface plasmon resonance biosensor for parallelized detection of protein biomarkers in diluted blood plasma. Biosens. Bioelectron. 2010, 26, 1656-1661. [CrossRef] [PubMed]

111. Sharma, P.; Asad, S.; Ali, A. Bioluminescent bioreporter for assessment of arsenic contamination in water samples of India. J. Biosci. 2013, 38, 251-258. [CrossRef] [PubMed]

112. Gui, Q.; Lawson, T.; Shan, S.; Yan, L.; Liu, Y.; Gui, Q.; Lawson, T.; Shan, S.; Yan, L.; Liu, Y. The application of whole cell-based biosensors for use in environmental analysis and in medical diagnostics. Sensors 2017, 17, 1623. [CrossRef] [PubMed]

113. Cardona-Maya, Y.; Villar, I.D.; Socorro, A.B.; Corres, J.M.; Arregui, F.J.; Botero-Cadavid, J.F. Etched and nanocoated sms fiber sensor for detection of salinity concentration. Proceedings 2017, 1, 333. [CrossRef]

114. Al-Qazwini, Y.; Noor, A.S.M.; Al-Qazwini, Z.; Yaacob, M.H.; Harun, S.W.; Mahdi, M.A. Refractive index sensor based on SPR in symmetrically etched plastic optical fibers. Sens. Actuators A Phys. 2016, 246, 163-169. [CrossRef]

115. Tahhan, S.R.; Chen, R.Z.; Huang, S.; Hajim, K.I.; Chen, K.P. Fabrication of fiber bragg grating coating with $\mathrm{TiO} 2$ nanostructured metal oxide for refractive index sensor. J. Nanotechnol. 2017, 2007, 9. [CrossRef]

116. Guo, T.; Liu, F.; Liang, X.; Qiu, X.; Huang, Y.; Xie, C.; Xu, P.; Mao, W.; Guan, B.-O.; Albert, J. Highly sensitive detection of urinary protein variations using tilted fiber grating sensors with plasmonic nanocoatings. Biosens. Bioelectron. 2016, 78, 221-228. [CrossRef] [PubMed]

117. Díaz-Herrera, N.; González-Cano, A.; Viegas, D.; Santos, J.L.; Navarrete, M.-C. Refractive index sensing of aqueous media based on plasmonic resonance in tapered optical fibres operating in the $1.5 \mu \mathrm{m}$ region. Sens. Actuators B Chem. 2010, 146, 195-198. [CrossRef]

118. Goswami, N.; Chauhan, K.K.; Saha, A. Analysis of surface plasmon resonance based bimetal coated tapered fiber optic sensor with enhanced sensitivity through radially polarized light. Opt. Commun. 2016, 379, 6-12. [CrossRef]

119. Zhu, S.; Pang, F.; Huang, S.; Zou, F.; Guo, Q.; Wen, J.; Wang, T.; Zhu, S.; Pang, F.; Huang, S.; et al. High sensitivity refractometer based on $\mathrm{TiO} 2$-coated adiabatic tapered optical fiber via ALD technology. Sensors 2016, 16, 1295. [CrossRef] [PubMed]

120. Tang, J.; Zhou, J.; Guan, J.; Long, S.; Yu, J.; Guan, H.; Lu, H.; Luo, Y.; Zhang, J.; Chen, Z. Fabrication of side-polished single mode-multimode-single mode fiber and its characteristics of refractive index sensing. IEEE J. Sel. Top. Quantum Electron. 2017, 23, 238-245. [CrossRef]

121. Kant, R.; Tabassum, R.; Gupta, B.D. Fiber optic SPR-based uric acid biosensor using uricase entrapped polyacrylamide gel. IEEE Photonics Technol. Lett. 2016, 28, 2050-2053. [CrossRef]

122. Lin, H.-Y.; Tsao, Y.-C.; Tsai, W.-H.; Yang, Y.-W.; Yan, T.-R.; Sheu, B.-C. Development and application of side-polished fiber immunosensor based on surface plasmon resonance for the detection of Legionella pneumophila with halogens light and $850 \mathrm{~nm}$-LED. Sens. Actuators A Phys. 2007, 138, 299-305. [CrossRef]

123. Dong, H.; Yu, J.; Yu, J.; Guan, H.; Guan, H.; Qiu, W.; Dong, J.; Lu, H.; Lu, H.; Tang, J.; et al. Coreless side-polished fiber for multimode interference and highly sensitive refractive index sensing. In Proceedings of the Optics in the Life Sciences Congress, San Diego, CA, USA, 15-17 April 2017; paper BoW4A.5. Optical Society of America: Washington, DC, USA, 2017; p. BoW4A.5.

124. Chen, J.; Shi, S.; Su, R.; Qi, W.; Huang, R.; Wang, M.; Wang, L.; He, Z.; Chen, J.; Shi, S.; et al. Optimization and application of reflective LSPR optical fiber biosensors based on silver nanoparticles. Sensors 2015, 15, 12205-12217. [CrossRef] [PubMed] 
125. Xie, Q.; Chen, Y.; Li, X.; Yin, Z.; Wang, L.; Geng, Y.; Hong, X. Characteristics of D-shaped photonic crystal fiber surface plasmon resonance sensors with different side-polished lengths. Appl. Opt. 2017, 56, 1550-1555. [CrossRef]

126. Huang, T. Highly sensitive SPR sensor based on D-shaped photonic crystal fiber coated with indium tin oxide at near-infrared wavelength. Plasmonics 2017, 12, 583-588. [CrossRef]

127. Rifat, A.A.; Ahmed, R.; Mahdiraji, G.A.; Adikan, F.R.M. Highly sensitive D-shaped photonic crystal fiber-based plasmonic biosensor in visible to near-IR. IEEE Sens. J. 2017, 17, 2776-2783. [CrossRef]

128. Zhang, C.; Li, Z.; Jiang, S.Z.; Li, C.H.; Xu, S.C.; Yu, J.; Li, Z.; Wang, M.H.; Liu, A.H.; Man, B.Y. U-bent fiber optic SPR sensor based on graphene/AgNPs. Sens. Actuators B Chem. 2017, 251, 127-133. [CrossRef]

129. Hasan, M.; Akter, S.; Rifat, A.; Rana, S.; Ali, S.; Hasan, M.R.; Akter, S.; Rifat, A.A.; Rana, S.; Ali, S. A highly sensitive gold-coated photonic crystal fiber biosensor based on surface plasmon resonance. Photonics 2017, 4, 18. [CrossRef]

130. Wu, T.; Shao, Y.; Wang, Y.; Cao, S.; Cao, W.; Zhang, F.; Liao, C.; He, J.; Huang, Y.; Hou, M.; et al. Surface plasmon resonance biosensor based on gold-coated side-polished hexagonal structure photonic crystal fiber. Opt. Express 2017, 25, 20313-20322. [CrossRef] [PubMed]

131. Tu, M.H.; Sun, T.; Grattan, K.T.V. LSPR optical fibre sensors based on hollow gold nanostructures. Sens. Actuators B Chem. 2014, 191, 37-44. [CrossRef]

132. Jiang, S.; Li, Z.; Zhang, C.; Gao, S.; Li, Z.; Qiu, H.; Li, C.; Yang, C.; Mei, L.; Liu, Y. A novel U-bent plastic optical fibre local surface plasmon resonance sensor based on a graphene and silver nanoparticle hybrid structure. J. Phys. D Appl. Phys. 2017, 50, 165105. [CrossRef]

133. Yang, X.C.; Lu, Y.; Liu, B.L.; Yao, J.Q. Temperature sensor based on photonic crystal fiber filled with liquid and silver nanowires. IEEE Photonics J. 2016, 8, 1-9. [CrossRef]

134. Su, Y.; Wei, Y.; Zhang, Y.; Liu, C.; Nie, X.; Zhu, Z.; Liu, L. Surface-plasmon-resonance-based optical fiber curvature sensor with temperature compensation by means of dual modulation method. Sensors 2018, 18, 2608. [CrossRef] [PubMed]

135. Mahdiraji, G.A.; Chow, D.M.; Sandoghchi, S.R.; Amirkhan, F.; Dermosesian, E.; Yeo, K.S.; Kakaei, Z.; Ghomeishi, M.; Poh, S.Y.; Gang, S.Y.; et al. Challenges and solutions in fabrication of silica-based photonic crystal fibers: an experimental study. Fiber Integr. Opt. 2014, 33, 85-104. [CrossRef]

136. Knight, J.C.; Birks, T.A.; Russell, P.S.J.; Atkin, D.M. All-silica single-mode optical fiber with photonic crystal cladding. Opt. Lett. 1996, 21, 1547-1549. [CrossRef] [PubMed]

137. Bise, R.T.; Trevor, D. Solgel-derived microstructured fibers: Fabrication and characterization. In Proceedings of the Optical Fiber Communication Conference and Exposition and The National Fiber Optic Engineers Conference, Anaheim, CA, USA, 6-11 March 2005; paper OWL6. Optical Society of America: Washington, DC, USA, 2005; p. OWL6.

138. Yajima, T.; Yamamoto, J.; Ishii, F.; Hirooka, T.; Yoshida, M.; Nakazawa, M. Low-loss photonic crystal fiber fabricated by a slurry casting method. Opt. Express 2013, 21, 30500-30506. [CrossRef] [PubMed]

139. Kumar, V.V.R.K.; George, A.K.; Reeves, W.H.; Knight, J.C.; Russell, P.S.J.; Omenetto, F.G.; Taylor, A.J. Extruded soft glass photonic crystal fiber for ultrabroad supercontinuum generation. Opt. Express 2002, 10, 1520-1525. [CrossRef] [PubMed]

140. Tajima, K. Low loss PCF by reduction of hole surface imperfection. In Proceedings of the 33rd European Conference and Exhibition of Optical Communication, Berlin, Germany, 16-20 September 2007; Post-Deadline Papers (published 2008). pp. 1-2.

141. Takeyasu, N.; Tanaka, T.; Kawata, S. Metal deposition deep into microstructure by electroless plating. Jpn. J. Appl. Phys. 2005, 44, L1134. [CrossRef]

142. Sazio, P.J.A.; Amezcua-Correa, A.; Finlayson, C.E.; Hayes, J.R.; Scheidemantel, T.J.; Baril, N.F.; Jackson, B.R.; Won, D.-J.; Zhang, F.; Margine, E.R.; et al. microstructured optical fibers as high-pressure microfluidic reactors. Science 2006, 311, 1583-1586. [CrossRef] [PubMed]

143. Boehm, J.; François, A.; Ebendorff-Heidepriem, H.; Monro, T.M. Chemical deposition of silver for the fabrication of surface plasmon microstructured optical fibre sensors. Plasmonics 2011, 6, 133-136. [CrossRef]

144. Sandlin, S.; Kinnunen, T.; Rämö, J.; Sillanpää, M. A simple method for metal re-coating of optical fibre Bragg gratings. Surf. Coat. Technol. 2006, 201, 3061-3065. [CrossRef] 
145. Lu, J.; Van Stappen, T.; Spasic, D.; Delport, F.; Vermeire, S.; Gils, A.; Lammertyn, J. Fiber optic-SPR platform for fast and sensitive infliximab detection in serum of inflammatory bowel disease patients. Biosens. Bioelectron. 2016, 79, 173-179. [CrossRef] [PubMed]

146. Liu, Q.; Yuan, H.; Liu, Y.; Wang, J.; Jing, Z.; Peng, W. Real-time biodetection using a smartphone-based dual-color surface plasmon resonance sensor. J. Biomed. Opt. 2018, 23, 047003. [CrossRef] [PubMed] 